University of Nebraska - Lincoln

DigitalCommons@University of Nebraska - Lincoln

Geochemistry of Sulfate Minerals: A Tribute to

Robert O. Rye

US Geological Survey

2005

\title{
Origin of secondary sulfate minerals on active andesitic stratovolcanoes
}

\author{
D.R. Zimbelman \\ G.O. Logic \\ Robert O. Rye \\ U.S. Geological Survey, rrye@usgs.gov \\ G.N. Breit \\ U.S. Geological Survey
}

Follow this and additional works at: https://digitalcommons.unl.edu/usgsrye

Part of the Geochemistry Commons

Zimbelman, D.R.; Rye, Robert O.; and Breit, G.N., "Origin of secondary sulfate minerals on active andesitic stratovolcanoes" (2005). Geochemistry of Sulfate Minerals: A Tribute to Robert O. Rye. 7.

https://digitalcommons.unl.edu/usgsrye/7

This Article is brought to you for free and open access by the US Geological Survey at DigitalCommons@University of Nebraska - Lincoln. It has been accepted for inclusion in Geochemistry of Sulfate Minerals: A Tribute to Robert O. Rye by an authorized administrator of DigitalCommons@University of Nebraska - Lincoln. 


\title{
Origin of secondary sulfate minerals on active andesitic stratovolcanoes
}

\author{
D.R. Zimbelman, ${ }^{\mathrm{a}, *}$, R.O. Rye ${ }^{\mathrm{b}}$, G.N. Breit ${ }^{\mathrm{b}}$ \\ ${ }^{\mathrm{a}}$ G.O. Logic, PO Box 1878, White Salmon, WA 98672, United States \\ ${ }^{\mathrm{b}}$ U.S. Geological Survey, Box 25046, MS 973, Denver, CO 80225, United States
}

Accepted 1 June 2004

\begin{abstract}
Sulfate minerals in altered rocks on the upper flanks and summits of active andesitic stratovolcanoes result from multiple processes. The origin of these sulfates at five active volcanoes, Citlaltépetl (Mexico), and Mount Adams, Hood, Rainier, and Shasta (Cascade Range, USA), was investigated using field observations, petrography, mineralogy, chemical modeling, and stable-isotope data. The four general groups of sulfate minerals identified are: (1) alunite group, (2) jarosite group, (3) readily soluble Fe- and Al-hydroxysulfates, and (4) simple alkaline-earth sulfates such as anhydrite, gypsum, and barite. Generalized assemblages of spatially associated secondary minerals were recognized: (1) alunite + silica \pm pyrite \pm kaolinite \pm gypsum \pm sulfur, (2) jarosite+alunite+silica; (3) jarosite+smectite+silica \pm pyrite, (4) Fe- and Al-hydroxysulfates+silica, and (5) simple sulfates + silica \pm Al-hydroxysulfates \pm alunite.

Isotopic data verify that all sulfate and sulfide minerals and their associated alteration assemblages result largely from the introduction of sulfur-bearing magmatic gases into meteoric water in the upper levels of the volcanoes. The sulfur and oxygen isotopic data for all minerals indicate the general mixing of aqueous sulfate derived from deep (largely disproportionation of $\mathrm{SO}_{2}$ in magmatic vapor) and shallow (oxidation of pyrite or $\mathrm{H}_{2} \mathrm{~S}$ ) sources. The hydrogen and oxygen isotopic data of alunite indicate the mixing of magmatic and meteoric fluids. Some alunite-group minerals, along with kaolinite, formed from sulfuric acid created by the disproportionation of $\mathrm{SO}_{2}$ in a condensing magmatic vapor. Such alunite, observed only in those volcanoes whose interiors are exposed by erosion or edifice collapse, may have $\delta^{34} \mathrm{~S}$ values that reflect equilibrium $\left(350 \pm 50{ }^{\circ} \mathrm{C}\right)$ between aqueous sulfate and $\mathrm{H}_{2} \mathrm{~S}$. Alunite with $\delta^{34} \mathrm{~S}$ values indicating disequilibrium between parent aqueous sulfate and $\mathrm{H}_{2} \mathrm{~S}$ may form from aqueous sulfate created in higher level low-temperature environments in which $\mathrm{SO}_{2}$ is scrubbed out by groundwater or where $\mathrm{H}_{2} \mathrm{~S}$ is oxidized. Jarosite-group minerals associated with smectite in only slightly altered volcanic rock are formed largely from aqueous sulfate derived from supergene oxidation of hydrothermal pyrite above the water table. Soluble Al- and Fehydroxysulfates form in low-pH surface environments, especially around fumaroles, and from the oxidation of hydrothermal pyrite. Anhydrite/gypsum, often associated with native sulfur and occasionally with small amounts of barite, also commonly form around fumaroles. Some occurrences of anhydrite/gypsum may be secondary, derived from the dissolution and reprecipitation of soluble sulfate. Edifice collapse may also reveal deep veins of anhydrite/gypsum \pm barite that formed from the mixing of saline fluids with magmatic sulfate and dilute meteoric water. Alteration along structures associated with both
\end{abstract}

\footnotetext{
* Corresponding author. Fax: +1 5094931149.

E-mail address: Zimbelman@gorge.net (D.R. Zimbelman).
} 
hydrothermal and supergene sulfates, as well as the position of paleo-water tables, may be important factors in edifice collapse and resulting debris flows at some volcanoes.

(c) 2004 Elsevier B.V. All rights reserved.

Keywords: Stratovolcanoes; Acid-sulfate alteration; Stable isotopes; Chemical modeling; Sulfates; Alunite; Jarosite; Hydroxysulfates

\section{Introduction}

Volcanoes annually expel more than $10.4 \mathrm{Mt}$ of sulfur as gases and particulates into Earth's atmosphere (Andres and Kasgnoc, 1998). As sulfurous gases and fluids move through relatively quiescent often glaciercapped volcanoes, a significant amount of sulfur is captured as native sulfur, and as sulfate and sulfide minerals during alteration of the rocks. In this paper, we describe the field relationships, petrography, chemical stability, and stable isotopic compositions of various sulfate minerals from altered flanks and summits of five active stratovolcanoes. These data are used to constrain the origin of the secondary sulfate minerals in terms of the processes responsible for their parent aqueous sulfate and associated depositional environments.

Sulfate minerals have been noted around active fumaroles on stratovolcanoes since ancient times. More recently, Stoiber and Rose (1974) reported a number of sulfates from fumarole encrustations associated with Central American volcanoes and summarized the literature on earlier discoveries. Africano and Bernard (2000) described various sulfate minerals in the fumarolic environment of Usu volcano, Japan. Zimbelman et al. (2000) described natroalunite and minamiite around fumaroles on the summit of Mount Rainier, Washington. Gypsum and anhydrite have been described around fumaroles at numerous volcanoes (e.g., Goff and McMurtry, 2000). Alunite, jarosite, and simple sulfates have also been noted in the interiors of stratovolcanoes where exposed by edifice collapse (Zimbelman, 1996). Acid-sulfate and related argillic alteration have been shown to detrimentally affect the stability of a volcanic edifice (Lopez and Williams, 1993; Zimbelman, 1996; Watters et al., 2000; Watters et al., 2001). Therefore, understanding the processes controlling the distribution and formation of hydrothermal alteration on volcano edifices may be important in hazard mitigation. The sulfate minerals that form directly from magmas or from deep hydrothermal processes often related to porphyry copper deposits, for example, are not discussed in this paper.

\section{Volcano descriptions}

We studied active andesitic and dacitic stratovolcanoes in the eastern Trans-Mexican Volcanic Belt and in the Cascade Range of the western United States (Fig. 1, inset). The volcanoes can be grouped by: (1) their seismicity, with relatively low levels at Mount Adams and Mount Shasta and more moderate levels at Citlaltépetl, Mount Hood, and Mount Rainier (Clarke and Carver, 1992; Stanley et al., 1996; Moran et al., 2000), and (2) the presence or lack of domes, with Citlaltépetl, Mount Hood, and Mount Shasta containing abundant domes and Mount Adams and Mount Rainier generally lacking domes. All of these volcanoes contain ice caps on their upper slopes, exposed hydrothermally altered sulfate-bearing rock, active fumaroles, and have undergone edifice collapse. Representative occurrences of sulfate minerals were sampled from outcrops on the summits and upper flanks of all of these volcanoes and from a debris flow at Mount Rainier.

\subsection{Citlaltépetl}

Citlaltépetl (Pico de Orizaba, $5675 \mathrm{~m}$ ), the easternmost major volcano in the ca. $1000-\mathrm{km}$ TransMexican Volcanic Belt, is North America's highest volcano and third highest peak. According to Carrasco-Núñez (1997) and Carrasco-Núñez and GomezTuena (1997), Citlaltépetl volcano consists of three superimposed stratovolcano cones, each of which was accompanied by dome intrusions, with most rock of andesitic or dacitic composition (Fig. 1). The conebuilding events occurred at 650 to $500 \mathrm{ka}, 290$ to 210 $\mathrm{ka}$, and in Holocene time, including as recently as 700 


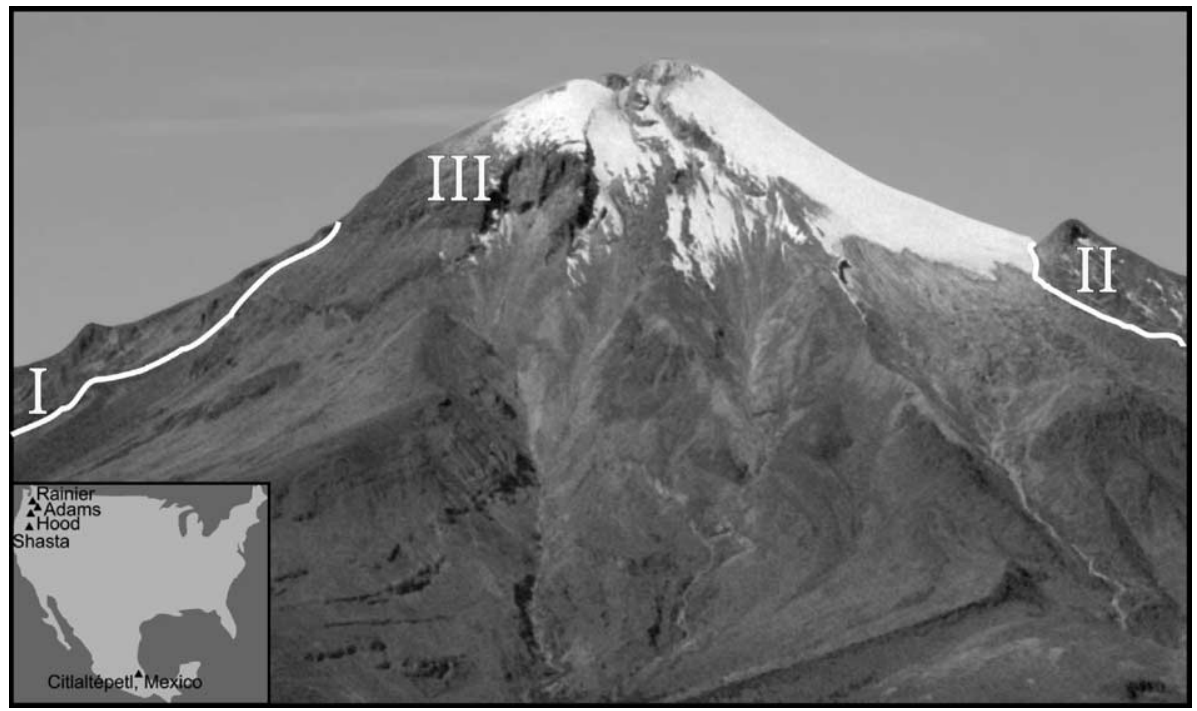

Fig. 1. Location map and east flank of Citlaltépetl volcano. The three cone-building stages include: (I) Torrecillas (oldest); (II) Espolón de Oro (middle); and (III) Citlaltépetl (youngest). The youngest stage includes historical lavas, which constructed the present summit cone, and numerous leveed block-lava flows and block-and-ash flows that veneer the lower flanks.

years BP. The first two cone-building stages were followed by major edifice-collapse events (Hoskuldsson and Robin, 1993). The collapse of the first stage cone formed a crater about $3.5 \mathrm{~km}$ in diameter and produced a debris avalanche of about $20 \mathrm{~km}^{3}$, with some debris traveling as far as $75 \mathrm{~km}$ to the Caribbean coast. An extensive, clay-rich $(10-16 \%$ smectite or kaolin) lahar also formed after collapse of the second stage. This lahar traveled $85 \mathrm{~km}$, covered an area of $143 \mathrm{~km}^{2}$, and had an estimated volume of $1.8 \mathrm{~km}^{3}$ (Hoskuldsson and Cantagrel, 1994). Most of the present summit cone and rocks preserved at the uppermost parts of the truncated first two stages (representing edifice failure horizons) contain extensive masses of sulfate-bearing hydrothermally altered rock (Fig. 2). Active fumaroles with centimeter-scale sulfate-mineral encrustations form a ca. $\sim 50 \times 100 \mathrm{~m}$ fumarole field west of the summit.

\subsection{Mount Adams}

Mount Adams volcano (3743 m) consists of a large, central, predominantly andesitic cone covering about $600 \mathrm{~km}^{2}$ and a peripheral, largely basaltic volcanic field that covers an additional $650 \mathrm{~km}^{2}$ (Hildreth and Fierstein, 1995). The oldest lavas form the central cone and are andesites and dacites, dated at 520-500 ka, whereas much of the summit region consists of andesite fragments, lava flows, agglutinate, and scoria that range in age from about 33 to $10 \mathrm{ka}$ (Hildreth and Lanphere, 1994). During drilling and sulfur-mining operations on Mount Adams' summit, Fowler (1934) reported steam (that he estimated to be about $75{ }^{\circ} \mathrm{C}$ ) and $\mathrm{H}_{2} \mathrm{~S}$ gas issuing from vents in and around the margins of the crater, mostly from within glacial crevasses. Today, there is little steam emission from the volcano, but the stench from $\mathrm{H}_{2} \mathrm{~S}$ is still strong on the northwestern plateau area. The volcano's upper flanks $(>3350 \mathrm{~m})$ and summit plateau regions host extensive hydrothermally altered rock masses (Fig. 3) containing massive sulfate-bearing zones (Fig. 4) and horizons rich in native sulfur. Vallance (1999) mapped about $5 \mathrm{~km}^{2}$ of altered rock and calculated that as much as $3.3 \mathrm{~km}^{3}$ of hydrothermally altered rock are present within the volcano. Potential landslide hazards were reviewed by Scott et al. (1995). In 1997, debris avalanches with volumes of approximately 5,000,000 $\mathrm{m}^{3}$ occurred in hydrothermally altered rock on the volcano's east and west sides.

\subsection{Mount Hood}

Mount Hood (3426 m) is an andesitic composite stratovolcano with a potential geothermal resource and 


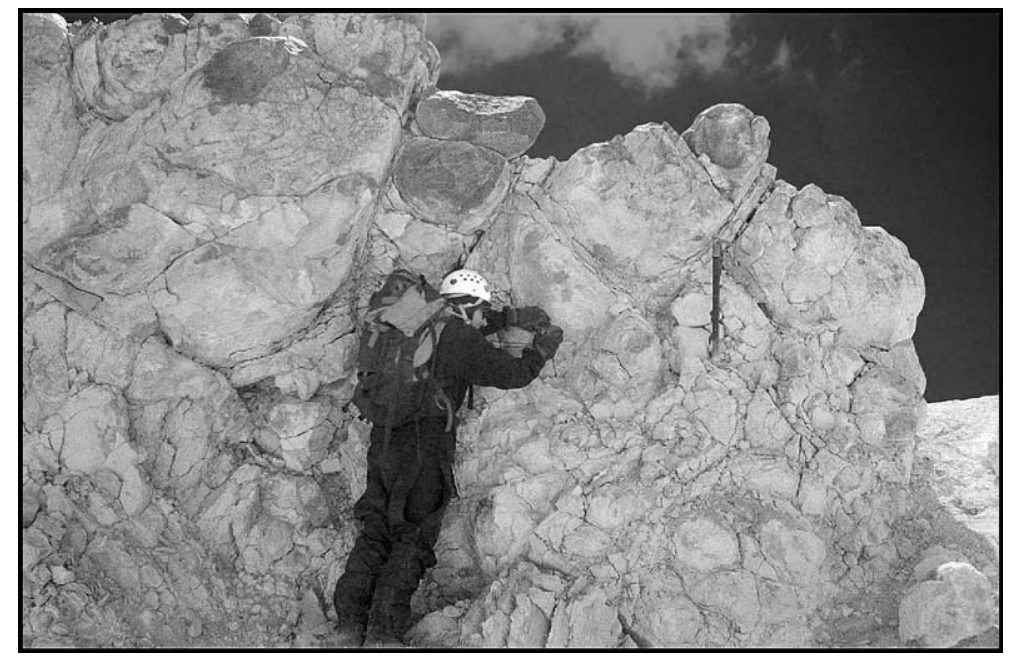

Fig. 2. Replacement alteration, Citlaltépetl volcano summit. Corestones of partly altered lava are surrounded by millimeter-scale, banded gypsum veinlets. Ice axe, $70 \mathrm{~cm}$ long.

an extensive post-glacial eruptive history (e.g., Cameron and Pringle, 1987). The past 30 ky have been dominated by the growth and collapse of dacitic domes extruded near the site of Crater Rock (Fig. 5). Dome-collapse events have generated hundreds of pyroclastic flows and lahars that have traveled at least $12 \mathrm{~km}$ and have built a broad, smooth fan on the south and southwest flanks of the volcano (Brantley and Scott, 1993; Scott et al., 1997). The most recent eruptive events occurred between 250 and 180 years ago (Crandell, 1980; Cameron and Pringle, 1987). Hydrothermal alteration was described by Bargar et al. (1993). Present thermal activity at Mount Hood occurs scattered throughout a semi-circular zone of fumaroles and hydrothermally altered and heated ground near Crater Rock (Fig. 6). At least 20 vents are present and most have temperatures of $50-85{ }^{\circ} \mathrm{C}$ (Wise, 1968; Zimbelman, unpublished data, 1999). During the Holocene, debris avalanches containing hydrothermally altered rock traveled more than $90 \mathrm{~km}$, into the

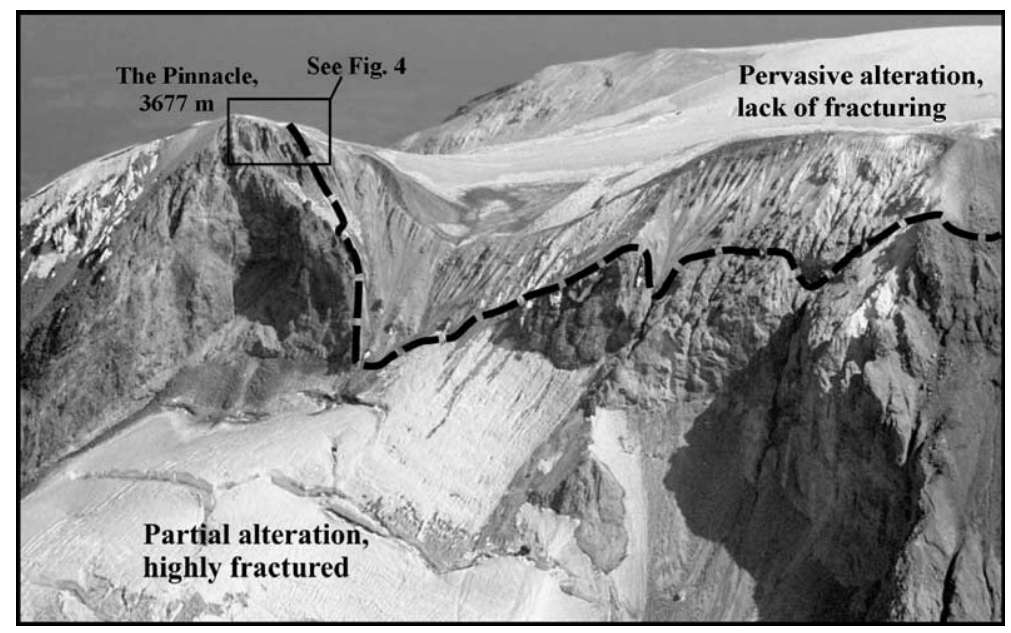

Fig. 3. Northwest summit plateau, Mount Adams volcano. Summit area consists of pervasive alteration and rock that fails to sustain fractures, weathering to a "badlands"-style morphology. Surrounding and below the pervasive alteration zone, alteration consists of partial replacement and the rock sustains intensive fractures. Width of view, $600 \mathrm{~m}$. 


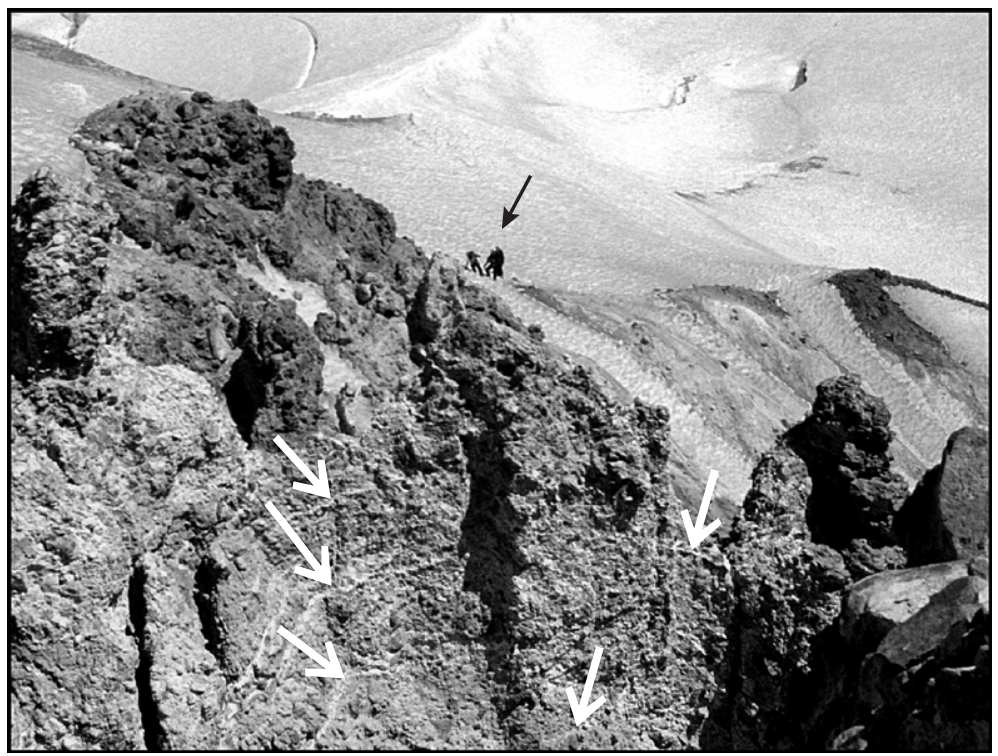

Fig. 4. Centimeter-scale, near-surface gypsum veinlets (white arrows) within partly altered $(\sim 50-70 \%)$ volcanic scoria and breccia at the Pinnacles area, Mount Adams. At the black arrow are three geologists near the contact between pervasively altered and unfractured summit rocks (right center) and partly altered, highly fractured rocks surrounding the summit (foreground). Width of view, $100 \mathrm{~m}$.

present Portland metropolitan area; another avalanche traveled north, crossed the Columbia River, and flowed several kilometers up the White Salmon River (Cameron and Pringle, 1987; Scott et al., 1997).

\subsection{Mount Rainier}

Mount Rainier volcano (4392 m) began to form at about $500 \mathrm{ka}$ (Sisson and Lanphere, 1999) and its most recent eruption, consisting of a light ash fall, occurred in 1894. Most rock on Mount Rainier is andesite (Fiske et al., 1963), deposited as massive or brecciated flows, with local interbedded tephra layers. The summit cone is at least $300 \mathrm{~m}$ high, $2 \mathrm{~km}$ wide, and consists of two overlapping craters, aligned east-west, both of which host ice caves related to active hydrothermal venting (Frank, 1995; Zimbelman et al., 2000).

Field- and satellite-based mapping has identified acid-sulfate and argillic altered rocks, mostly confined to an ENE-WNW structural zone (Zimbelman, 1996; Crowley and Zimbelman, 1997; Bruce, 1997). Along this structural zone, Mount Rainier has undergone

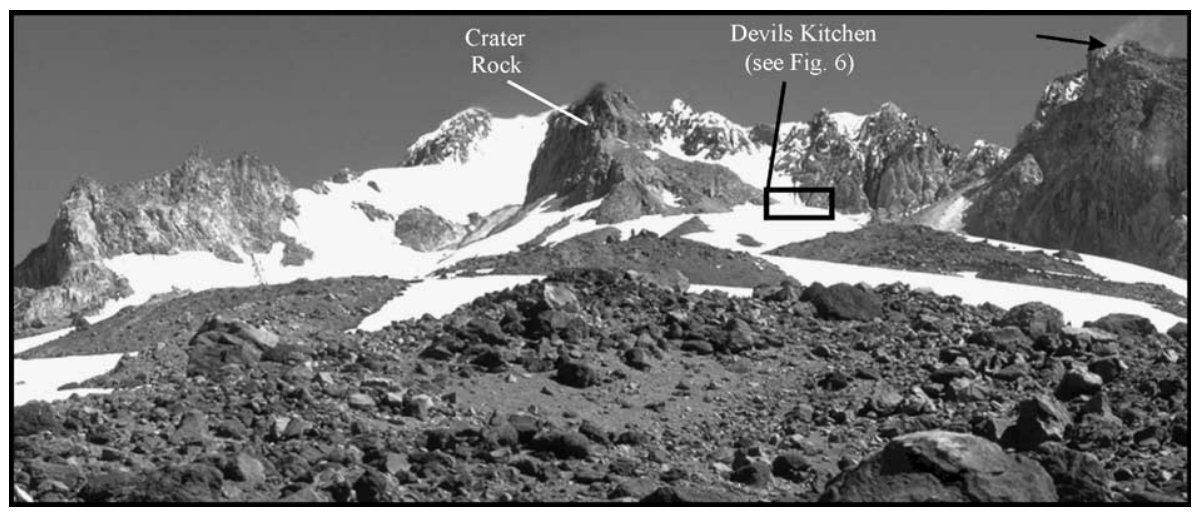

Fig. 5. Panorama of Mount Hood's summit amphitheater, looking north and including Crater Rock dome and Devils Kitchen fumarole area. Black arrow, fumarole. Width of view, $1 \mathrm{~km}$. 


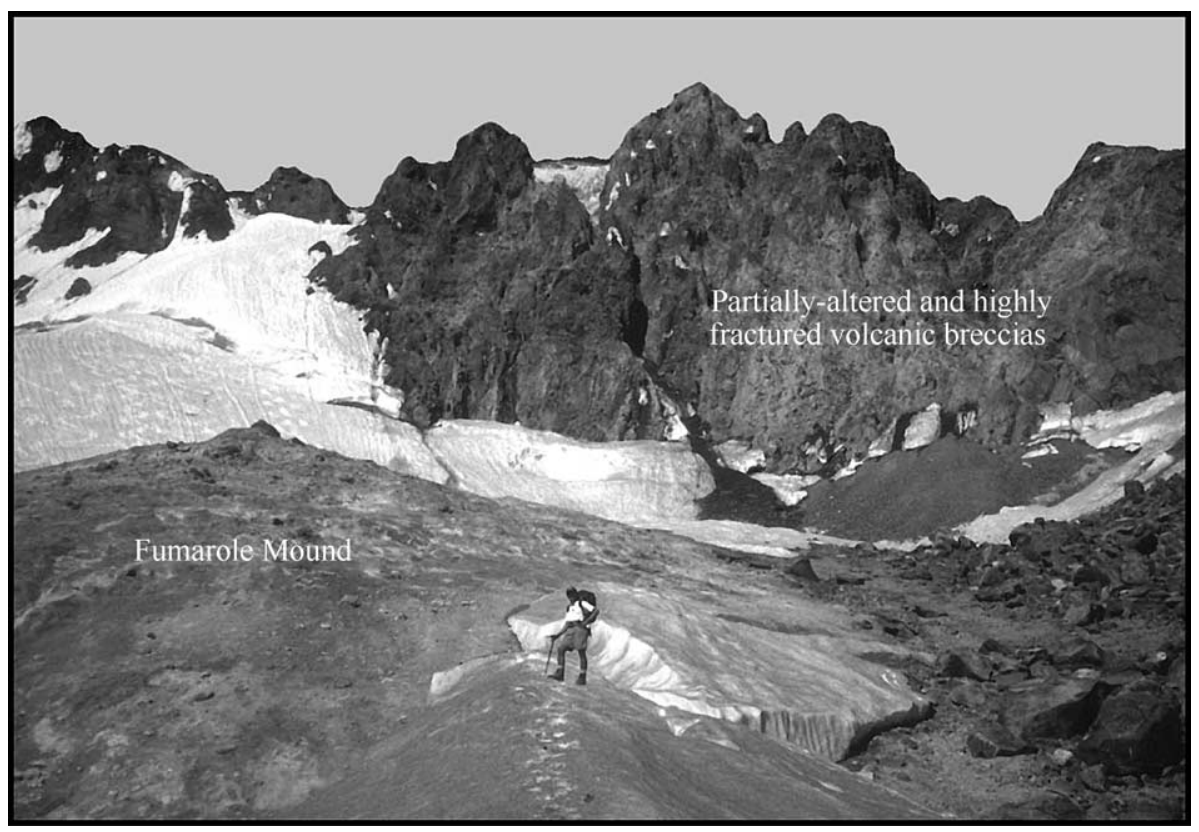

Fig. 6. Devils Kitchen fumarole area, Mount Hood. Center, fumarole precipitate mound ( $\sim 50 \mathrm{~m}$ across) where native sulfur and smectite clays are actively precipitating.

repeated edifice failures with associated lahars (Fig. 7). All of the largest and most of the smaller collapse events were sourced in the altered rock masses (Fig. 8;
Crandell, 1971). The volcano's summit cone represents partial rebuilding of a formerly higher summit that collapsed to form the Osceola Mudflow 5600

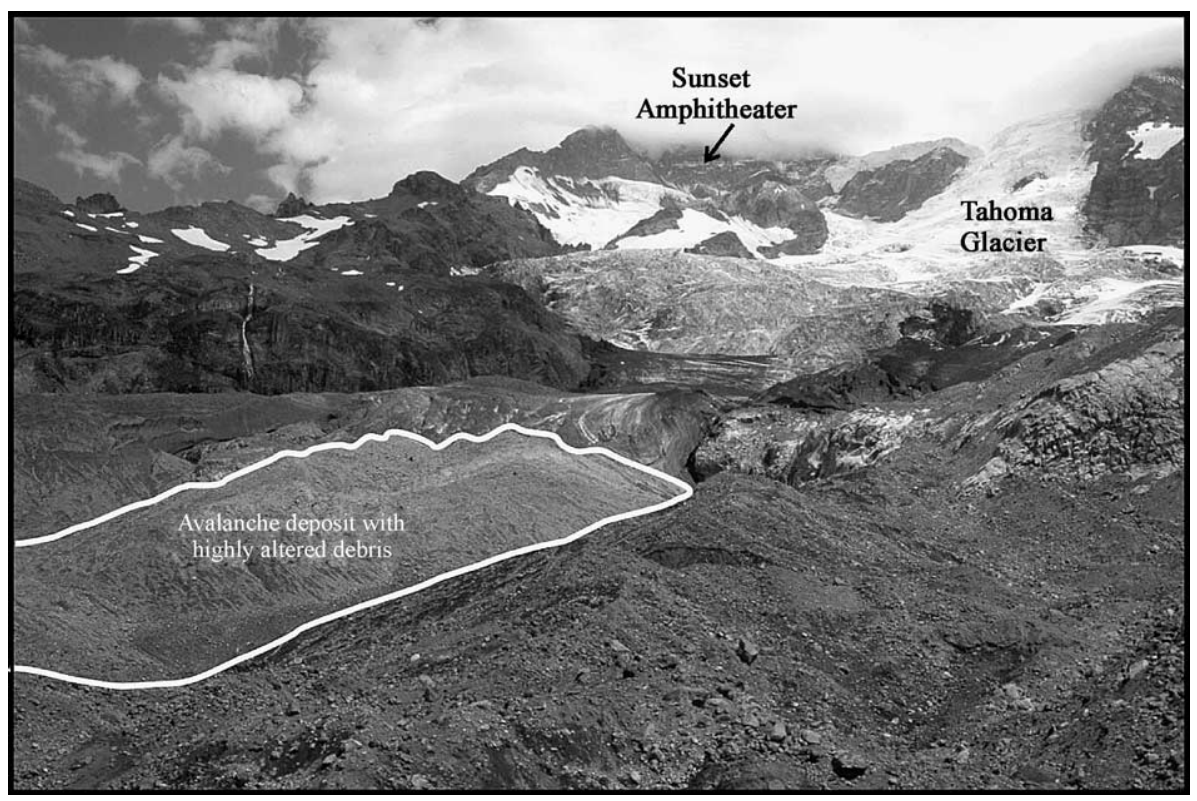

Fig. 7. Debris-avalanche deposit, Puyallup River, Mount Rainier. Deposit contains hydrothermally altered rock, including boulders of massive sulfate (mostly anhydrite/gypsum). Black arrow, Sunset Amphitheater pumice layer shown in Fig. 8. 


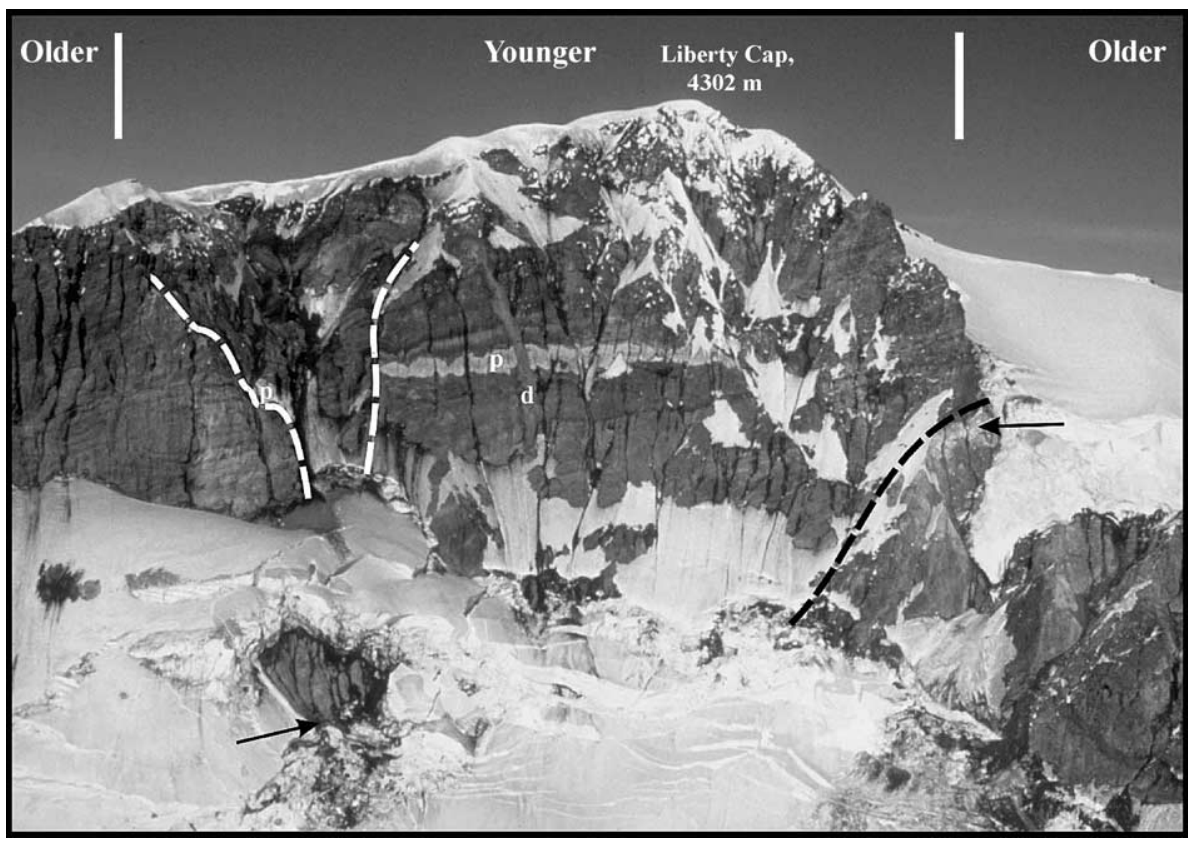

Fig. 8. Sunset Amphitheater area, Mount Rainier volcano, showing older and younger volcanic packages separated by faults/failure surfaces (dashed lines). Older rocks (left and right sides of photograph) contain partial to pervasive replacement alteration, including massive zones (to $10 \mathrm{~m}$ ) of anhydrite (arrow at far right), which locally include barite with hypersaline fluid inclusions (arrow at bottom left). Younger package of partly altered rocks, including white pumice (p), was deposited within a crater that formed from collapse of the older, altered rock. Dikes (d) intrude older and younger packages. Width of view, $900 \mathrm{~m}$.

years ago (Crandell, 1976). Recent studies by the authors (Rye et al., 2003) indicate that jarosite is abundant in the matrix and pyrite is a common minor mineral in clasts of Osceola Mudflow. Large (up to 10 m) veins of gypsum occur on the exposed scarps created during edifice collapse (Zimbelman, 1996).

\subsection{Mount Shasta}

Snow-clad Mount Shasta (4317 m) is a compound stratovolcano consisting of overlapping cones centered on four or more main vents (Sherrod and Smith, 1990). The cone-building periods produced andesite lava flows, block-and-ash flows, and mudflows, followed by more silicic eruptions of domes and pyroclastic flows. Two of the main eruptive centers were constructed during Holocene time and the most recent eruptions occurred about 200 years BP (Miller, 1980). Fumarole activity is weak, consisting of numerous vents and steaming ground throughout an area of $\sim 100$ $\mathrm{m}^{2}$ near the summit dome. Reconnaissance study of Mount Shasta determined that its surface contains less altered rock than the other large Cascade stratovolcanoes (Zimbelman, unpublished data, 1999). However, both the Hotlum and Shastina cones contain fractures and localized zones of acid-sulfate alteration. One of the world's largest debris-avalanche deposits covers $675 \mathrm{~km}^{2}$, has a volume of $45 \mathrm{~km}^{3}$, and occurred at about $300 \mathrm{ka}$ during a collapse of ancestral Mount Shasta (Crandell et al., 1984; Crandell, 1989). Shasta is the only volcano studied on which jarosite has not been recognized.

\section{Methods}

\subsection{Field studies}

The volcanoes studied have extensive glacial cover on their upper slopes, requiring sampling where rocks are exposed along ridges, within craters, and across many steep headwalls. Although our samples are limited to rock currently exposed at the surface of the volcanoes, some samples were collected from expo- 
sures formed by edifice collapse, and thus represent the interior of the volcano as deep as several hundred meters below ancient surfaces. Navigation was achieved with a hand-held GPS unit (accurate to $\sim 30 \mathrm{~m})$ and the summit crater of Citlaltépetl was mapped with the assistance of a laser-rangefinder unit (accurate to $\sim 1 \mathrm{~m}$ ). Most of the fieldwork in the Cascade Range was from tree line to summit, at elevations above $3660 \mathrm{~m}$. Fieldwork at Citlaltépetl ranged from about $4400 \mathrm{~m}$ to the summit, $5675 \mathrm{~m}$. Fieldwork was conducted in the Cascade Range during 1993-1999 and at Citlaltépetl during 1999 and 2000 .

\subsection{Laboratory studies}

Rock samples were studied by standard thin section, X-ray diffraction (XRD), and scanning electron microscopy (SEM). XRD analysis identified minerals present in bulk-rock samples and mineral separates. Diffraction patterns were collected using $\mathrm{Cu} K \alpha$ X-radiation with a Siemens D500 instrument equipped with a graphite monochromator. Mineral identification was facilitated using the Jade 5.0 program. Interpretation of the XRD results commonly indicated a range in mineral compositions, particularly for alunite-group minerals; peak shapes and positions were commonly consistent with the presence of alunite, natroalunite, and minamiite, as well as phosphate analogs. In general, XRD identification required concentrations in excess of two weight percent. A JEOL 5800 scanning electron microscope equipped with an Oxford ISIS energy-dispersion spectrometer system (EDS) was used to examine samples and acquire compositional data on the finegrained alteration minerals. The SEM-EDS analyses confirmed the compositional variation of the alunitegroup minerals.

Because the altered rock is typically fine-grained, physical separation of alteration minerals for stableisotope studies was not always possible. Alunite and jarosite for stable-isotope analyses were separated by the methods of Wasserman et al. (1992). Native sulfur and gypsum were typically coarser grained, and were separated by hand picking. Sulfate in soluble minerals, such as gypsum, anhydrite, and hydroxysulfates, was leached with distilled water and precipitated as barium sulfate. The $\mathrm{pH}$ of extraction water typically reflected the samples' predominant alteration minerals $(100 \mathrm{~mL}$ water to $10 \mathrm{~g}$ of lightly ground rock) as follows: rocks containing soluble $\mathrm{Fe}$ and $\mathrm{Al}$ hydroxysulfates had $\mathrm{pH}$ values of 2-4, alunite-bearing rock had $\mathrm{pH}$ values of $4-5$, whereas rock containing jarosite and smectite as the principal alteration minerals had $\mathrm{pH}$ values of $6-7.5$. These differences are consistent with the different origins of jarosite and soluble hydroxysulfates in the debris deposits of Mount Rainier, as discussed later.

\section{Results and discussion}

\subsection{Mineralogy}

Sulfate minerals identified as occurring at each volcano are summarized in Table 1. Four major groups of sulfate minerals were noted: (1) alunite and its chemical analogs such as natroalunite, minamiite, and florencite; (2) jarosite and chemical analogs such as natrojarosite; (3) soluble Al- and Fehydroxysulfates, including alunogen, meta-alunogen, potassium alum, quenstedtite, and copiapite, and (4) simple sulfates such as gypsum, anhydrite, and barite. As discussed below, these minerals form from aqueous sulfate derived from a number of processes in different environments.

Reduced sulfur in the form of native sulfur and sulfide minerals is markedly less abundant than sulfate minerals on the volcanoes studied. Native sulfur is variably abundant in surface samples from Mount Adams, Mount Hood, and Citlaltépetl, but was absent in samples from Mount Shasta and Mount Rainier. Only a few samples from local alteration areas on Mount Shasta contain greigite. Pyrite is locally abundant in samples from Mount Rainier and is common in pebble- to cobble-size clasts in the Osceola Mudflow deposits. Clasts containing pyrite include a variety of associated secondary phases including smectite, jarosite, alunite, gypsum and native sulfur.

The distribution and form of secondary silica is also a product of the hydrothermal solutions. Discrete $\mathrm{SiO}_{2}$ phases detected in most samples by XRD include opal-C and opal-CT. Opal-A and tridymite were detected in a few samples; quartz was absent. No consistent pattern of $\mathrm{SiO}_{2}$ phase was associated with sulfate mineral assemblage. $\mathrm{SiO}_{2}$ is also a component 
Table 1

Sulfate minerals, native sulfur, and iron sulfides at the Cascade and Citlaltépetl stratovolcanoes

\begin{tabular}{|c|c|c|c|c|c|c|}
\hline Mineral & Composition & Rainier $(64)^{\mathrm{a}}$ & Adams (41) & Hood (54) & Shasta (25) & Citlaltépetl (21) \\
\hline \multicolumn{7}{|l|}{ Alunite group } \\
\hline Alunite & $\mathrm{KAl}_{3}\left(\mathrm{SO}_{4}\right)_{2}(\mathrm{OH})_{6}$ & $\mathrm{X}$ & $\mathrm{X}$ & $\mathrm{X}$ & $\mathrm{X}$ & $\mathrm{X}$ \\
\hline Natroalunite & $\mathrm{NaAl}_{3}\left(\mathrm{SO}_{4}\right)_{2}(\mathrm{OH})_{6}$ & $\mathrm{X}$ & & & & \\
\hline Minamiite & $(\mathrm{Na}, \mathrm{Ca}, \sim)_{2} \mathrm{Al}_{6}\left(\mathrm{SO}_{4}\right)_{4}(\mathrm{OH})_{12}$ & $\mathrm{X}$ & & & & \\
\hline Florencite & $(\mathrm{REE}, \mathrm{Ce}) \mathrm{Al}_{3}\left(\mathrm{SO}_{4}\right)_{2}(\mathrm{OH})_{6}$ & $\mathrm{X}$ & & & & \\
\hline \multicolumn{7}{|l|}{ Jarosite group } \\
\hline Jarosite & $\mathrm{KFe}_{3}\left(\mathrm{SO}_{4}\right)_{2}(\mathrm{OH})_{6}$ & $\mathrm{X}$ & $\mathrm{X}$ & $\mathrm{X}$ & & $\mathrm{X}$ \\
\hline Natrojarosite & $\mathrm{NaFe}_{3}\left(\mathrm{SO}_{4}\right)_{2}(\mathrm{OH})_{6}$ & $\mathrm{X}$ & & & & \\
\hline Ammoniojarosite & $\mathrm{NH}_{4} \mathrm{Fe}_{3}\left(\mathrm{SO}_{4}\right)_{2}(\mathrm{OH})_{6}$ & $\mathrm{X}$ & & & & \\
\hline \multicolumn{7}{|l|}{ Other $\mathrm{Fe}-\mathrm{Al}$ sulfates } \\
\hline Potassium alum & $\mathrm{KAl}\left(\mathrm{SO}_{4}\right)_{2} \cdot 12 \mathrm{H}_{2} \mathrm{O}$ & $X$ & $X$ & $\mathrm{X}$ & $\mathrm{X}$ & $\mathrm{X}$ \\
\hline Alunogen & $\mathrm{Al}_{2}\left(\mathrm{SO}_{4}\right)_{3} \cdot 17 \mathrm{H}_{2} \mathrm{O}$ & $\mathrm{X}$ & $\mathrm{X}$ & & & \\
\hline Basaluminite & $\mathrm{Al}_{4} \mathrm{SO}_{4}(\mathrm{OH})_{10} \cdot 4 \mathrm{H}_{2} \mathrm{O}$ & $\mathrm{X}$ & & & & \\
\hline Meta-alunogen & $\mathrm{Al}_{4}\left(\mathrm{SO}_{4}\right)_{6} \cdot 27 \mathrm{H}_{2} \mathrm{O}$ & $\mathrm{X}$ & & & & \\
\hline Quenstedtite & $\mathrm{Fe}_{2}\left(\mathrm{SO}_{4}\right)_{3} \cdot 11 \mathrm{H}_{2} \mathrm{O}$ & $\mathrm{X}$ & & & & \\
\hline Copiapite & $\mathrm{Fe}^{2+} \mathrm{Fe}_{4}^{3+}\left(\mathrm{SO}_{4}\right)_{6}(\mathrm{OH})_{2} \cdot 20 \mathrm{H}_{2} \mathrm{O}$ & $\mathrm{X}$ & & & & \\
\hline \multicolumn{7}{|l|}{ Simple sulfates } \\
\hline Gypsum/anhydrite & $\mathrm{CaSO}_{4} \cdot 2 \mathrm{H}_{2} \mathrm{O} / \mathrm{CaSO}_{4}$ & $\mathrm{X}$ & $X$ & $\mathrm{X}$ & & $\mathrm{X}$ \\
\hline Barite & $\mathrm{BaSO}_{4}$ & $\mathrm{X}$ & & & & $\mathrm{X}$ \\
\hline Native Sulfur & $\mathrm{S}$ & & $X$ & $\mathrm{X}$ & & $\mathrm{X}$ \\
\hline Pyrite/Greigite & $\mathrm{FeS}_{2} / \mathrm{Fe}_{3} \mathrm{~S}_{4}$ & $\mathrm{X}$ & & & $\mathrm{X}$ & \\
\hline
\end{tabular}

a Value in () is the number of samples examined.

of smectite and kaolin that are common alteration phases.

\subsection{Petrology}

Alunite-group minerals occur at all five volcanoes and are consistently associated with abundant secondary silica and, locally, gypsum and pyrite. Alunite minerals are generally $1 \mu \mathrm{m}$ pseudocubic rhombs, but locally have lengths of up to $10 \mu \mathrm{m}$. XRD results and SEM analyses verified the occurrence of natroalunite with lesser amounts of alunite (sensu stricto) and minamiite. Fig. 9 shows alunite crystals that grew within and on spherical silica associated with red iron oxide, possibly hematite. Alunite is consistently coarser grained than natroalunite in all samples (Fig. 9B). Complex compositional variations in alunite are illustrated by EDS element maps, which reveal a wellcrystallized K-rich core successively surrounded by a $\sim 1-\mu \mathrm{m}$ zone rich in $\mathrm{Ca}$ and $\mathrm{P}$, a poorly crystalline $\mathrm{Na}-$ rich zone, and a Fe-rich zone (Fig. 10). These abrupt changes in anion and cation chemistry imply changing compositions of the hydrothermal fluid.

Several samples from Citlaltépetl and Mount Adams contain relatively coarse jarosite $(>5 \mu \mathrm{m})$ associated with alunite and silica (Fig. 11), whereas weakly altered samples contain fine-grained jarosite that is commonly associated with smectite and silica. Jarosite likely has two origins, one directly related to hydrothermal alteration, and a second attributed to supergene oxidation of pyrite. The shape of the cavity hosting the jarosite within a mass of alunite (Fig. 11A) resembles a prismatic mineral, possibly a pyroxene. The spatial separation of alunite and jarosite in this sample might be directly related to the relative availability of $\mathrm{Fe}$ and $\mathrm{Al}$ within a rock subjected to acid-sulfate alteration. Jarosite in rock containing smectite, argillized mafic minerals, and relatively fresh plagioclase is attributed to supergene oxidation of sulfide. Fig. 12 illustrates dissolution textures on pyrite in a sample containing jarosite. The low $\mathrm{pH}$ necessary to form jarosite (Stoffregen, 1993; Rye and Alpers, 1997) is inconsistent with the occurrence of plagioclase in the same rock. The preservation of plagioclase is explained by restricting the low-pH fluids to limited volumes near the sites of jarosite formation. This inference is consistent with the limited occurrence of jarosite in weakly altered samples to voids lined with smectite or silica. 
A.

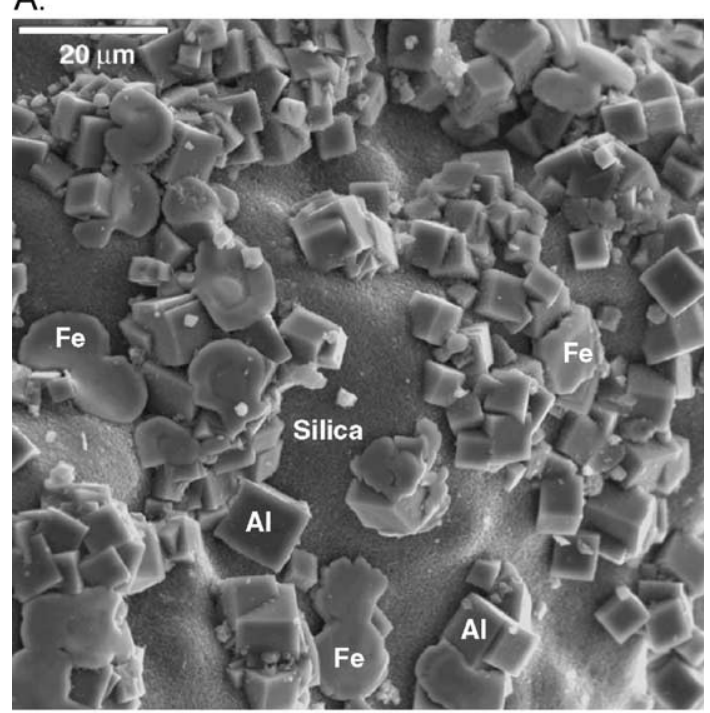

B.

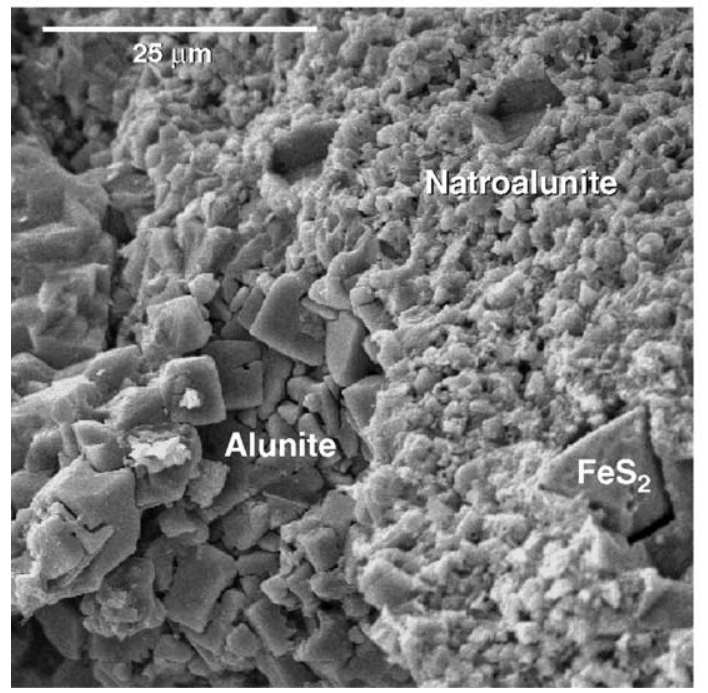

Fig. 9. SEM micrographs of (A) alunite (Al) from Citlaltépetl intergrown with cristobalite (silica) and coated with red iron oxide (Fe). Note intergrowth of alunite crystals. (B) Alunite and natroalunite in a sample from Mount Rainier. Note the smaller grain size of natroalunite relative to alunite.

Soluble hydroxysulfate minerals and simple sulfates are generally found in rock composed mainly of secondary silica and lacking primary igneous phases. Iron and $\mathrm{Al}$ hydroxysulfates were identified by XRD analyses and by the ability of the minerals to decrease the $\mathrm{pH}$ of distilled water to $<4$ when rock samples were mixed with water. Pyrite was a rare constituent of samples containing hydroxysulfates. The simple sulfate minerals, including gypsum, anhydrite, and barite, are commonly of millimeters to centimeters in size. Gypsum and anhydrite occur as coarse crystals that fill veins and medium-grained veinlets. The simple sulfates typically are present in rock containing secondary silica and possibly alunite. Exposures of the simple sulfates occur in the summit scarps at Mount Rainier, the summit cone of Citlaltépetl, and on the summit plateau region of Mount Adams. Crystals of barite have been observed in secondary gypsum/anhydrite veins on Mount Rainer. The barite contains saline (5.7 to $>24$ equivalent wt. $\% \mathrm{NaCl}$ ) fluid inclusions with formation temperatures of $230 \pm 25^{\circ} \mathrm{C}$ (Zimbelman, 1996) but their low freezing point depression indicate the fluids are probably $\mathrm{CaCl}_{2}$ rather than $\mathrm{NaCl}$ rich.

In general, the sulfate minerals have five consistent mineral assemblages which can be broadly related to steam-heated, magmatic-hydrothermal, and supergene environments discussed below. (1) Smectite and pyrite without sulfates are characteristic of slightly altered rock commonly containing fresh plagioclase with variably altered ground mass and mafic minerals. This assemblage may develop on the low-temperature envelope of a magmatic-hydrothermal environment. The oxidation of pyrite during exposure to air adds jarosite and goethite to this assemblage. (2) The assemblage jarosite+alunite + silica is interpreted to be the product of more intense hydrothermal alteration in which smectite and remnants of mafic minerals are removed from the rock. This assemblage may be a product of steam-heated alteration involving the oxidation of $\mathrm{H}_{2} \mathrm{~S}$. (3) The assemblage of alunite+silica \pm pyrite \pm kaolinite \pm sulfur \pm gypsum occurs in rocks lacking primary constituents of the original volcanic rock other than traces of plagioclase. This assemblage is considered a product of magmatichydrothermal alteration overlapped, in places, by later steam-heated alteration. (4) The assemblage gypsum/ anhydrite \pm barite in fracture fillings may be magmatic-hydrothermal. But when secondary silica, hydroxysulfates and traces of alunite are also present the fracture fillings may largely be supergene. (5) The assemblage silica+aluminum hydroxysulfates that lacks indication of primary sulfides are likely an aspect of the steam-heated environment, possibly 

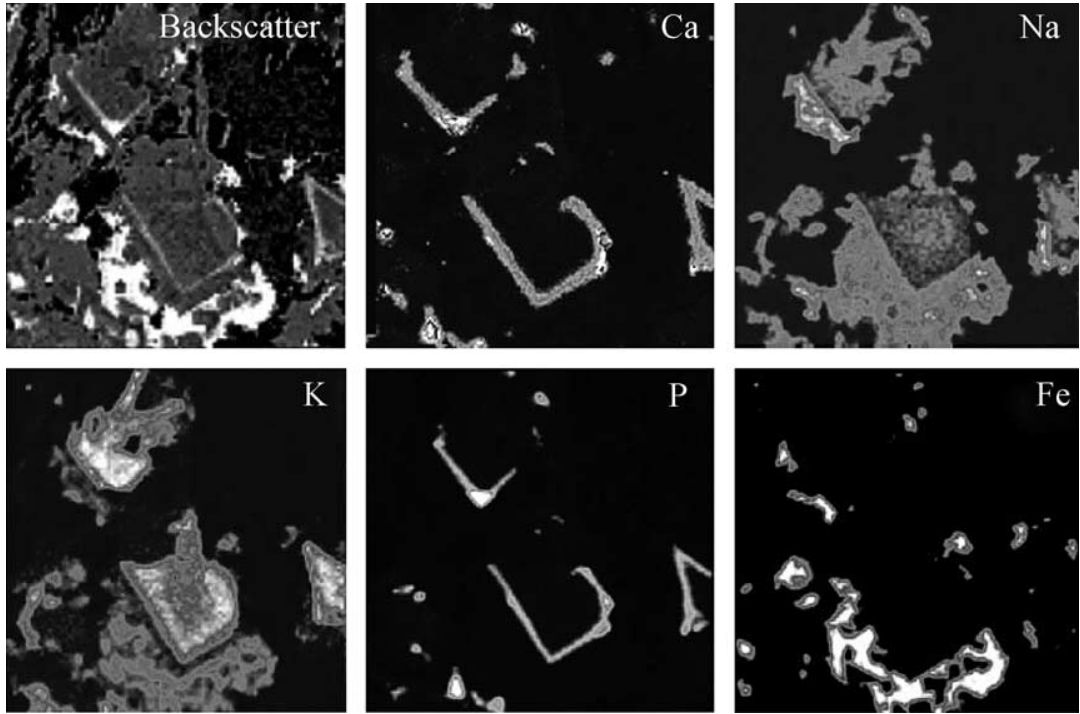

Fig. 10. Semi-quantitative element maps of a sample of Mount Rainier alunite-group minerals; Ca, Calcium; Na, Sodium; K, Potassium; P, Phosphorous; Fe, Iron.

indicative of fumarole deposition. The degree of development of each assemblage varies from place to place in a given volcano, and from volcano to volcano, reflecting a somewhat unique evolution of hydrothermal fluids at individual volcanoes. Supergene oxidation of sulfides and redistribution of soluble sulfates undoubtedly modifies the basic associations established by hydrothermal processes.

\subsection{Geochemical modeling}

Alteration assemblages were evaluated with calculated stability diagrams to estimate the $\mathrm{pH}$ and ion compositions of the fluids that formed the alteration minerals and to judge the relative stability of phases in an assemblage. Because of the temporal and spatial complexities of these volcanic hydrothermal systems, reaction-path modeling was not attempted. The stability diagrams were constructed using Geochemist's Workbench (Bethke, 1998) with the LLNLV8R6 database. Several alteration minerals detected by XRD have insufficient thermodynamic data for calculation of stability fields, so the calculated stability diagrams should be regarded as preliminary representations of fluids that may have formed some of the major alteration minerals. The abundances of potassium and sulfate in the altering fluids were estimated from the fluid compositions described by Frank (1995) as a natural acid-sulfate water in the Cascades. Cristobalite was used to approximate silica activity because of the abundance of opal-C in many of the altered rocks. Although opal-C is likely to have a slightly greater solubility than cristobalite, their similarity in structure and the limitation of reliable thermodynamic data make cristobalite the best approximation. The modeling is limited to temperatures of $0-250{ }^{\circ} \mathrm{C}$ to describe conditions characteristic of the shallow alteration represented by most of our samples. Stability diagrams for sulfate minerals at higher temperatures are presented by Holland and Malinin (1979) and Stoffregen (1993).

Fig. 13 depicts the relative stability of $\mathrm{Al}$ and $\mathrm{Fe}^{3+}$ phases as a function of $\mathrm{pH}$ and the ratio of $\mathrm{Fe}^{3+} / \mathrm{Al}^{3+}$ at $100{ }^{\circ} \mathrm{C}$. The observed spatial association of hydrothermal jarosite with alunite is consistent with a fluid saturated with cristobalite, local sources of $\mathrm{Al}$ (feldspars), and low $\mathrm{pH}$. With continued passage of slightly reducing and acidic hydrothermal fluids, the $\mathrm{Fe}^{3+} / \mathrm{Al}^{3+}$ ratio may decrease by reduction of $\mathrm{Fe}^{3+}$ to $\mathrm{Fe}^{2+}$ or removal of $\mathrm{Fe}^{3+}$. Under conditions of $\mathrm{Fe}^{3+} /$ $\mathrm{Al}^{3+}=<0005$, alunite is stable. Note that jarosite and alunite share a stability boundary at low pH in Fig. 13, consistent with the assemblage shown in Fig. 11A. A higher $\mathrm{Fe}^{3+} / \mathrm{Al}^{3+}$ ratio is likely within the cast 


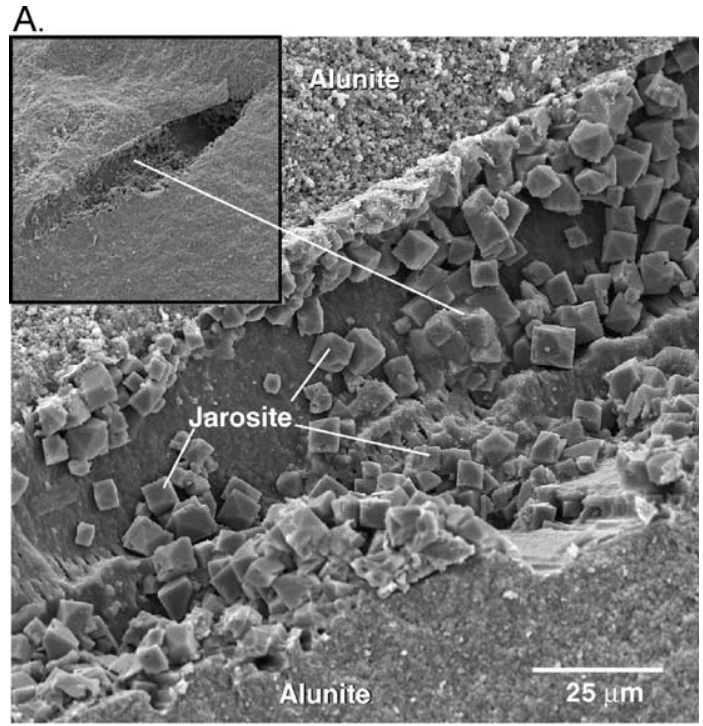

B.

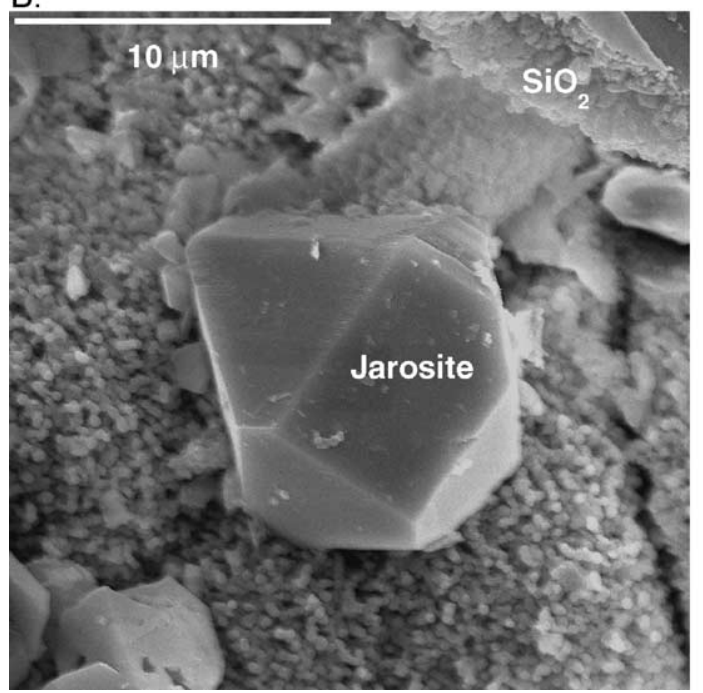

Fig. 11. SEM micrographs of (A) jarosite crystals in an elongate cavity surrounded by alunite in a sample from Citlaltépetl. (B) An unusually large jarosite crystal on a bed of silica in a sample containing natroalunite from Mount Adams. Small crystals are also jarosite.

formerly occupied by a mafic mineral. In contrast to the alunite-jarosite association, some alunite at Citlaltépetl (Fig. 9A) is associated with red iron oxide (hematite), which may imply formation at a $\mathrm{pH}$ too high for jarosite to form (Fig. 13). At lower temperatures likely for supergene weathering, a different mineral association is anticipated (Fig. 14). The

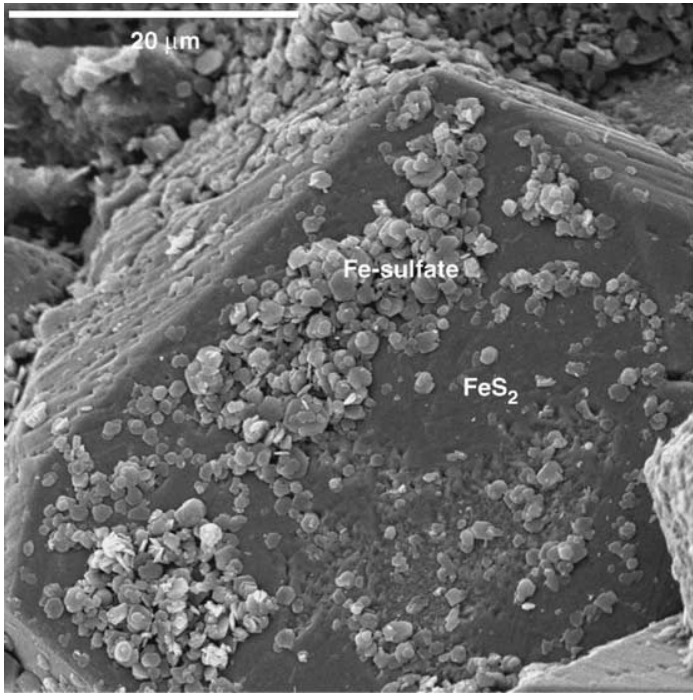

Fig. 12. SEM micrograph of partly etched $\mathrm{FeS}_{2}$ in a sample containing jarosite-rimmed vugs. Small platy crystals spatially associated with dissolution surfaces are tentatively identified as jarosite with low contents of $\mathrm{K}$ and $\mathrm{Na}$ (hydronium jarosite?).

consistent association of jarosite with smectite (nontronite) in samples containing minor goethite conforms to the phases predicted by the low-temperature stability diagram.

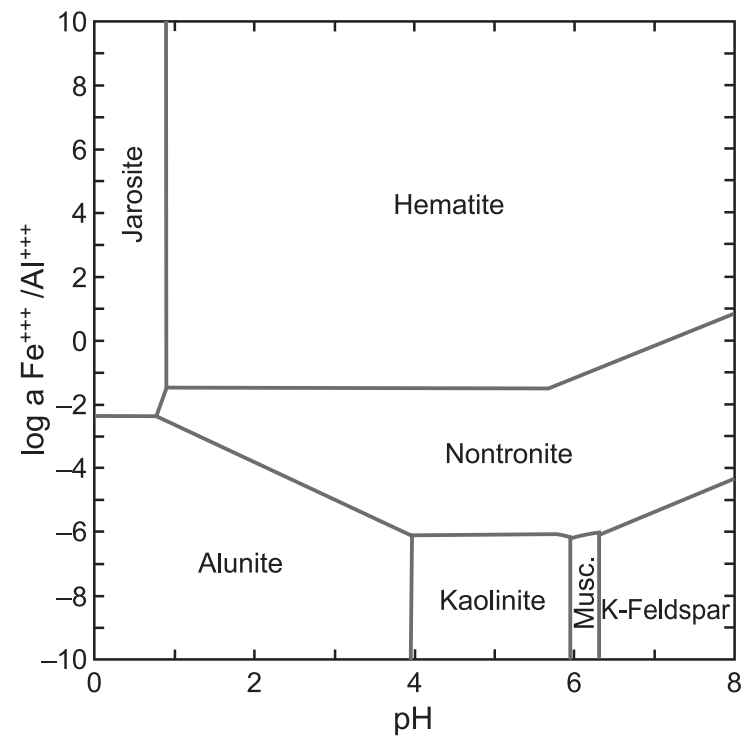

Fig. 13. Stability diagram of the $\mathrm{Al}-\mathrm{Fe}-\mathrm{Si}-\mathrm{S}-\mathrm{K}-\mathrm{O}$ system as a function of the ratio of $\mathrm{pH}$ versus $\mathrm{Fe}^{3+} / \mathrm{Al}^{3+}$. Diagram calculated at $100{ }^{\circ} \mathrm{C}$, with $\log$ activity $\mathrm{SO}_{4}^{2-}=-1.87, \log$ activity $\mathrm{K}^{+}$of -3.2 , silica activity fixed by cristobalite (Musc.-muscovite). 


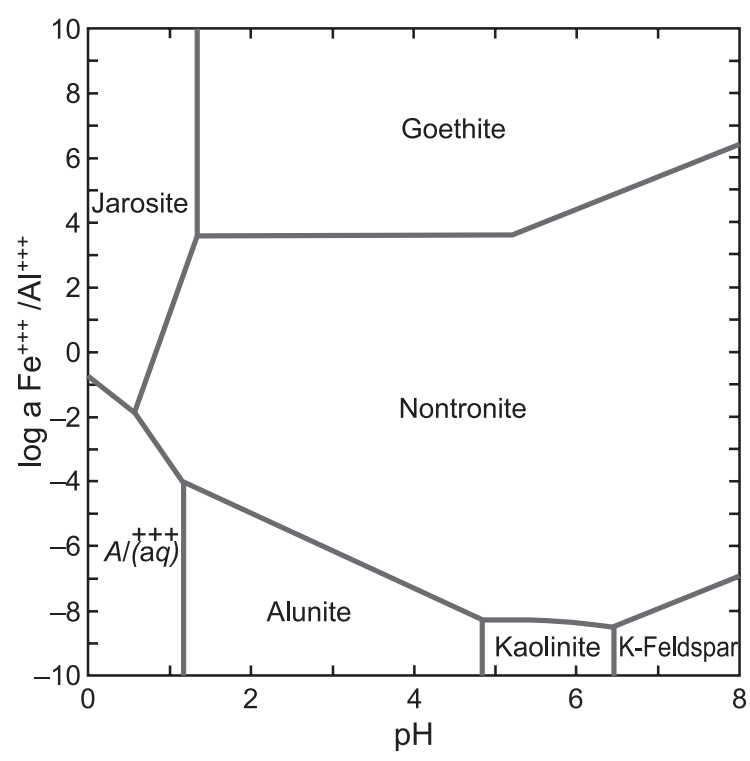

Fig. 14. Stability diagram of the $\mathrm{Al}-\mathrm{Fe}-\mathrm{Si}-\mathrm{S}-\mathrm{K}-\mathrm{O}$ system as a function of $\mathrm{pH}$ versus $\mathrm{Fe}^{3+} / \mathrm{Al}^{3+}$ at $15{ }^{\circ} \mathrm{C} . \mathrm{SO}_{4}^{2-}=-1.87, \log$ activity $\mathrm{K}^{+}$of -3.2 , and silica activity set by cristobalite. Hematite was suppressed because of its absence in the supergene assemblage.

Deeply eroded volcanoes commonly expose Kfeldspar and mica beneath the zone of acid-sulfate alteration (e.g., Henley and McNabb, 1978). The mica and K-feldspar are considered to be products of hydrothermal alteration at temperatures that exceed the threshold for disproportionation of $\mathrm{SO}_{2}$, as is discussed below. In the absence of disproportionation or oxidation of reduced sulfur phases, $\mathrm{pH}$ values are likely to remain above the stability boundaries for these silicates (Fig. 15).

The sensitivity of Al-sulfate and silicate phases to $\mathrm{pH}$ and potassium activity is illustrated in Fig. 15A. The association of alunite and kaolinite observed in several samples is consistent with calculated phase boundaries. The observation that acid-soluble sulfates are detected only in rocks lacking feldspar is consistent with their formation in rock that has lost the capacity to neutralize the parent acid fluids. Both alum and alunogen-like minerals are stable only at very low $\mathrm{pH}$. Quite likely these minerals are restricted to sublimates formed in a vapor-dominated fumarole environment containing significant amounts of sulfuric acid and relatively high amounts of dissolved solids. Temperature variations also affect the stability of the Al-sulfate minerals. Fig. 15B illustrates that alum is preferred relative to alunite with decreasing temperature at extremely low $\mathrm{pH}$. Precipitation of alum is likely as acid fluids cool during movement from the thermally heated interior portions of the volcano outward toward the glacier-capped summit.
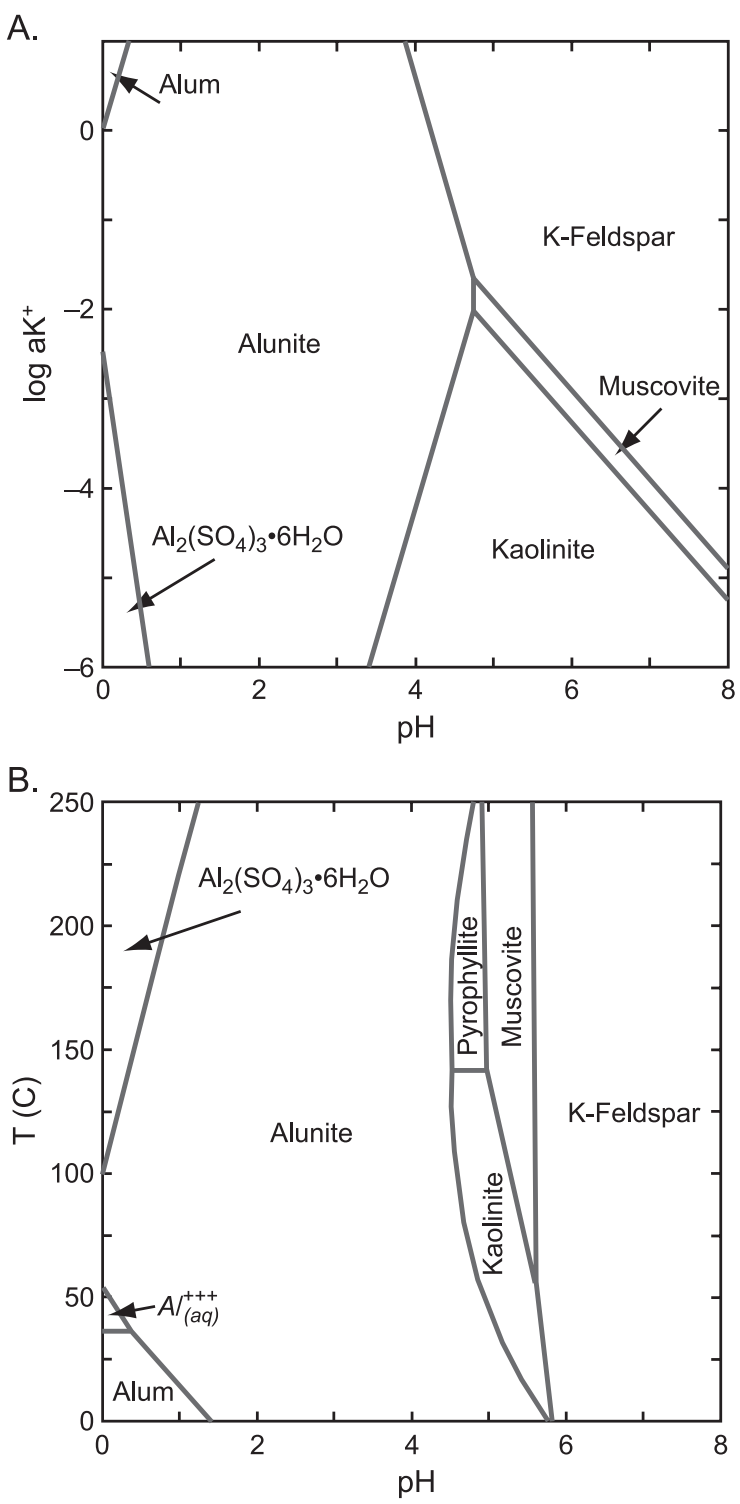

Fig. 15. Stability diagrams of $\mathrm{Al}-\mathrm{Si}-\mathrm{S}-\mathrm{K}-\mathrm{O}$ calculated with $\log$ activity of $\mathrm{SO}_{4}^{2-}$ of -1.301 and cristobalite saturation. (A) $\mathrm{pH}$ versus $\mathrm{K}^{+}$, calculated at $100{ }^{\circ} \mathrm{C}$; (B) of $\mathrm{pH}$ versus temperature the $\log$ activity of $\mathrm{K}^{+}=-2.5$. Concentrations of sulfate and potassium are greater than used for Figs. 13 and 14 to include stability fields for alum and aluminum sulfate. 
Preservation of the $\mathrm{Al}$ hydroxysulfates is tentatively attributed to intergrowth with precipitating silica, with encapsulation protecting the soluble phases.

The stability of anhydrite and barite is directly related to the relative abundance of cations and Al. Fig. 16 illustrates the relative stability of these simple sulfates. Both anhydrite and barite are favored under conditions of increasing $\mathrm{pH}$ because of the decreased solubility of $\mathrm{Al}$ needed to stabilize alunite.

\subsection{Sources or origins of aqueous sulfate}

In this section, we review the sources of aqueous sulfate in the context of hydrothermal processes on stratovolcanoes and review the stable-isotope criteria to recognize the sources. Generally, little primary sulfur $\left(<200 \mathrm{~g} \mathrm{t}^{-1}\right.$, Ohmoto and Goldhaber, 1997) is present in andesitic volcanic rocks. Ultimately, the hydrothermal sulfate minerals are products of magmatic fluids and of aqueous sulfate produced by the reactions of acid volcanic gases, especially $\mathrm{H}_{2} \mathrm{~S}$ and $\mathrm{SO}_{2}$, with atmosphere, water and rocks. These fluids are exsolved from underlying magmas. During high

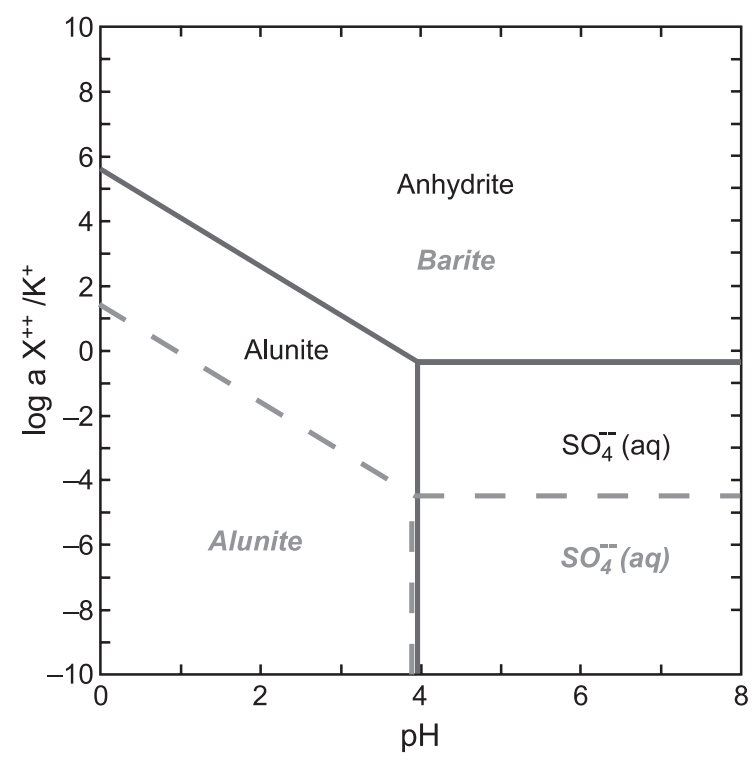

Fig. 16. Stability diagram of sulfate species as a function of $\mathrm{pH}$ and $\mathrm{X}^{2+} / \mathrm{K}^{+}$where $X=\mathrm{Ca}^{2+}$ or $\mathrm{Ba}^{2+}$. Dashed lines define the stability boundaries of the barium system and solid lines are the calcium system. Diagram calculated for a temperature of $100{ }^{\circ} \mathrm{C}$, with $\log$ activity of $\mathrm{SO}_{4}^{2-}$ of $-1.87, \log$ activity of $\mathrm{K}^{+}=-3.2$, activity of silica set by cristobalite, and activity of $\mathrm{Al}$ is fixed by kaolinite. rates of degassing, volcanic gases largely escape to the atmosphere. As degassing rates decrease, the gases condense and dissolve in meteoric water to form low-pH fluids that react with the surrounding rock. Several cycles of condensation and degassing may occur until compositionally evolved fluids degas from the water-saturated zone into the shallow unsaturated zone, forming additional low-pH fluids. In addition, sublimates may form from the gases that exit through fumaroles on the surface of the volcano. Any pyrite that is formed will be subject to oxidation by both low-temperature meteoric water and higher temperature magmatic vapor exposed to atmospheric oxygen.

Five sources or origins of aqueous sulfate can be recognized in different parts of stratovolcanoes. These are the disproportionation of $\mathrm{SO}_{2}$ in magmatic vapor, saline magmatic liquids, oxidation of $\mathrm{H}_{2} \mathrm{~S}$, oxidation of pyrite, and recycled sulfate. In a broad sense, the aqueous sulfate is derived by processes that occur in environments similar to those (magmatic-hydrothermal, steam-heated, supergene) recognized from the study of ore deposits as discussed in Rye et al. (1992) and Rye (this volume).

The locations of these processes in a dormant active stratovolcano are shown diagrammatically in Fig. 17. A similar diagram is discussed in more detail in Rye (this volume). At deep levels, beginning at about $400^{\circ} \mathrm{C}$, near the brittle-ductile transition, $\mathrm{SO}_{2}$ from a condensing magmatic vapor plume disproportionates to produce $\mathrm{H}_{2} \mathrm{~S}$ and $\mathrm{H}_{2} \mathrm{SO}_{4}$. The condensed magmatic vapor plume mixes with high- to lowtemperature meteoric water depending on the summit hydrology and of the rate of volcanic degassing. $\mathrm{H}_{2} \mathrm{~S}$ in the magmatic vapor reacts with $\mathrm{Fe}^{+}$in the rocks to produce pyrite. $\mathrm{H}_{2} \mathrm{~S}$ may escape to the atmosphere through fumaroles or react with atmospheric oxygen and meteoric water to produce more $\mathrm{H}_{2} \mathrm{SO}_{4}$. Sublimates may form around fumaroles. Under special circumstances, such as when meteoric water circulates deeply during edifice collapse, aqueous sulfate from saline magmatic liquid fluids may rise to higher levels in the volcano. At shallow levels, pyrite will be oxidized to aqueous sulfate when exposed to atmospheric oxygen. Secondary sulfate minerals can go through cycles of dissolution and re-precipitation on the wet/dry surface of active glacier-covered stratovolcanoes. 


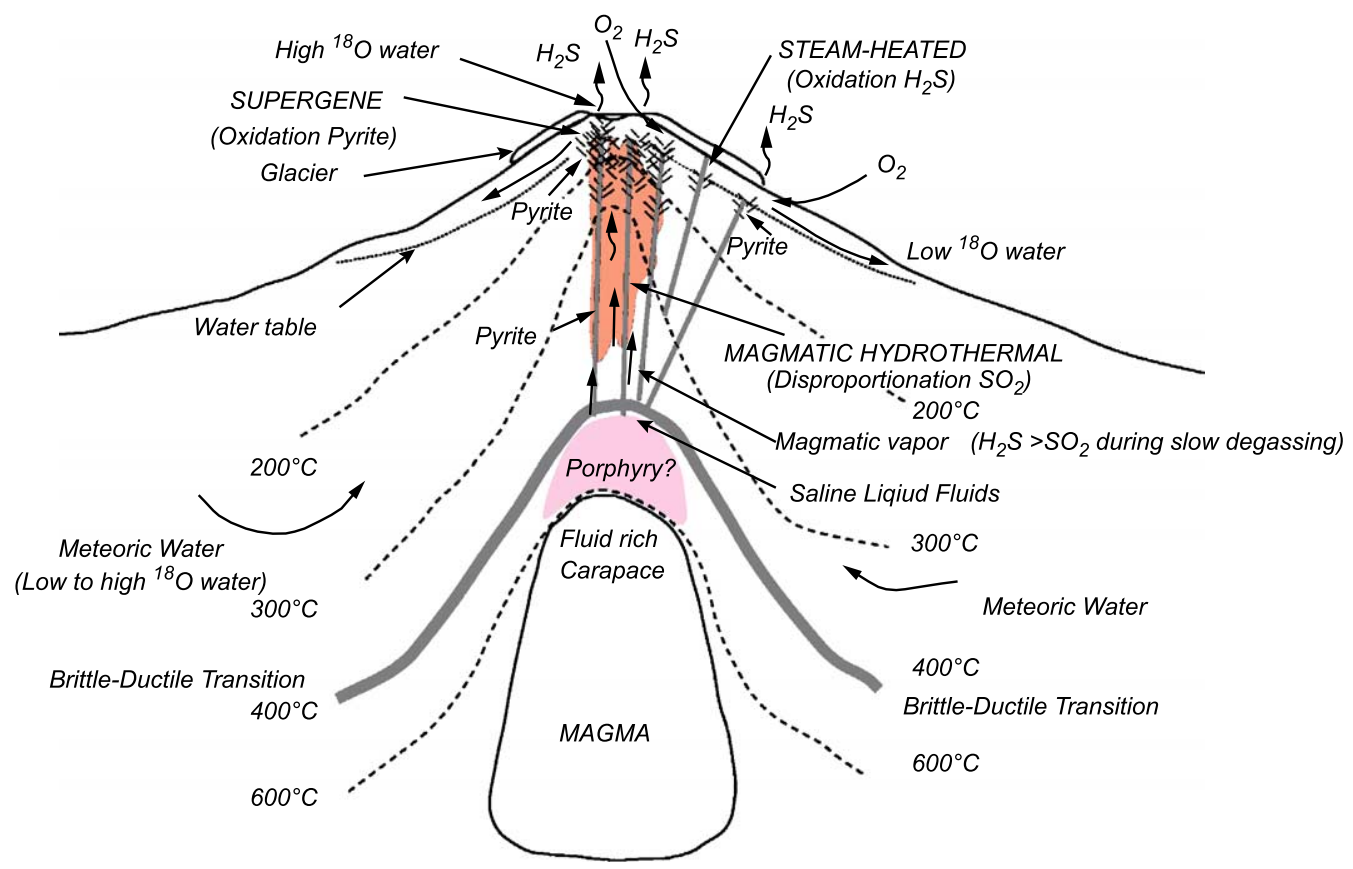

Fig. 17. Model showing location of magmatic-hydrothermal, steam-heated and supergene acid-sulfate environments and the processes of aqueous sulfate formation in these environments in an active but dormant stratovolcano. See text for references.

\subsubsection{Disproportionation of $\mathrm{SO}_{2}$}

If magma degassing rates are slow enough for magmatic vapor to condense, a magmatic-hydrothermal environment will form (Rye et al., 1992; Rye, this volume). In this environment, beginning at about 400 ${ }^{\circ} \mathrm{C}$ in the presence of water, $\mathrm{SO}_{2}$ disproportionates to aqueous sulfate and $\mathrm{H}_{2} \mathrm{~S}$ according to the reaction $4 \mathrm{SO}_{2}+4 \mathrm{H}_{2} \mathrm{O}=\mathrm{H}_{2} \mathrm{~S}+3 \mathrm{H}_{2} \mathrm{SO}_{4}$ (Holland, 1965). Subsequent alteration of andesite produces the assemblage alunite + kaolinite + silica+pyrite. The pyrite forms as $\mathrm{H}_{2} \mathrm{~S}$ reacts with $\mathrm{Fe}$ in the rocks. At high temperatures, the $\mathrm{H}_{2} \mathrm{~S}$ and aqueous sulfate will be in equilibrium and the sulfur isotopic composition of coexisting sulfide and sulfate minerals will reflect the temperature of deposition. Because of the effect of pressure on the equilibrium of sulfur species in fluids exsolved from deep magmas and because of the effect of later equilibration with Fe-bearing minerals in calc-alkalic igneous rocks below the brittle-ductile transition, the fluids will typically have $\mathrm{H}_{2} \mathrm{~S} / \mathrm{SO}_{2}$ ratios that are $\geq 1$ (Rye, this volume). As a result, the $\delta^{34} \mathrm{~S}$ value of $\mathrm{H}_{2} \mathrm{~S}$ and ensuing pyrite will typically be similar to the value for bulk sulfur in the system, whereas the value of alunite will be much higher (Rye, 1993). Excess $\mathrm{H}_{2} \mathrm{~S}$ vents toward the surface, where it either escapes to the atmosphere or is oxidized by atmospheric oxygen to produce more $\mathrm{H}_{2} \mathrm{SO}_{4}$. Sulfur isotopic equilibrium between aqueous sulfate and $\mathrm{H}_{2} \mathrm{~S}$ may not be attained if disproportionation of $\mathrm{SO}_{2}$ occurs as it is scrubbed out by low-temperature groundwater at high levels in stratovolcanoes. When equilibrium does not occur, the $\delta^{34} \mathrm{~S}$ values of aqueous sulfate can be similar to, or higher than those for $\mathrm{H}_{2} \mathrm{~S}$, depending on the degree of sulfur isotopic exchange between aqueous sulfate and $\mathrm{H}_{2} \mathrm{~S}$. Alunite that forms from aqueous sulfate derived from the disproportionation of $\mathrm{SO}_{2}$ will have $\delta \mathrm{D}$ values ranging from those of magmatic water (typically $-30 \%$ o to $-90 \%$ ) to meteoric water (typically $-90 \%$ o to $-180 \%$ ).

\subsubsection{Magmatic brines}

If aqueous fluids undergo boiling after exsolving from the magma, the fluids will split into a dilute vapor (discussed above) and saline liquid (Fournier, 1987; Giggenbach, 1997). These liquids can become the source of ore fluids in porphyry-type or even shallower epithermal-type ore deposits (Henley and Ellis, 1983; Rye, 1993; Arribas, 1995; Giggenbach, 
1997). One of the distinguishing features of sulfate derived from this source is a high salinity in fluid inclusions. However, these magmatic-fluid brines are dense and they probably reach high levels of stratovolcanoes only under special conditions, such as when pressure is suddenly released or when the brines are entrained in deep circulating meteoric water (e.g., Bethke et al., this volume).

\subsubsection{Oxidation of $\mathrm{H}_{2} \mathrm{~S}$}

$\mathrm{H}_{2} \mathrm{~S}$ that is degassed from a magma or deeper hydrothermal fluids may form sulfuric acid when it is oxidized by atmospheric oxygen in a steam-heated environment according to the summary reaction $\mathrm{H}_{2} \mathrm{~S}+2 \mathrm{O}_{2}=\mathrm{H}_{2} \mathrm{SO}_{4}$. This environment typically occurs in geothermal fields (Rye et al., 1992). Alunite can form from the aqueous sulfate in this environment but, as pointed out by Stoffregen (1993), jarosite can develop instead of alunite under exceptionally low-pH and high- $\mathrm{Fe}^{3+}$ activity conditions such as when the $\mathrm{pH}$ buffering capacity of the host rocks has been destroyed. Jarosite or alunite formed in this manner will initially have low $\delta^{34} \mathrm{~S}$ values (typically near $0 \pm 2 \%$ o) reflecting kinetic oxidation of the system's $\mathrm{H}_{2} \mathrm{~S}$. Sulfur isotope exchange rates between aqueous sulfate and $\mathrm{H}_{2} \mathrm{~S}$ are significant at the low $\mathrm{pH}$ and elevated temperatures of the steam-heated environment (Ohmoto and Lasaga, 1982). So, at the low $\mathrm{pH}$ values required for jarosite or alunite formation, the precursor aqueous sulfate formed by the oxidation of $\mathrm{H}_{2} \mathrm{~S}$ will tend to exchange sulfur with the (streaming) unoxidized $\mathrm{H}_{2} \mathrm{~S}$ prior to jarosite or alunite precipitation. This exchange will increase the $\delta^{34} \mathrm{~S}$ values of the aqueous sulfate. Steam-heated aqueous sulfate will initially be fairly large (10\%o to $15 \%$ o). However, at low $\mathrm{pH}$ the aqueous sulfate may exchange oxygen with high-temperature magmatic vapor or ${ }^{18} \mathrm{O}$ enriched low-temperature meteoric water, resulting in even larger $\delta^{18} \mathrm{O}_{\mathrm{SO}_{4}}$ values in precipitated sulfate minerals. The degree of sulfur and oxygen isotopic exchange depends on the flux of $\mathrm{H}_{2} \mathrm{~S}$, temperature, and the residence time of the aqueous sulfate prior to alunite or jarosite deposition (Rye et al., 1992; Ebert and Rye, 1997).

\subsubsection{Oxidation of pyrite}

To the extent that pyrite occurs on stratovolcanoes and is exposed by edifice collapse or erosion, its oxidation by low-temperature meteoric water or hightemperature magmatic vapor can be a source of sulfate for supergene acid-sulfate alteration. This oxidation may produce alunite, disordered kaolinite, Fe-oxide minerals such as hematite and goethite, and jarosite and soluble hydroxysulfates. Supergene jarosite typically forms above the water table whereas alunite forms at or below the water table (Rye et al., 2000). The textures, mineralogy, and forms of supergene acidsulfate assemblages are commonly similar to those formed in steam-heated environments. Where sulfidation of rock is vein-controlled, supergene alteration may occur as curtains extending down structures for vertical distances of hundreds of meters. The oxidation of sulfides is a complex process, but basically it is governed by two reactions, one involving largely molecular atmospheric oxygen and the other involving entirely meteoric water (Taylor et al., 1984). The $\delta^{34} \mathrm{~S}$ values of alunite or jarosite will be same as that of precursor pyrite, whereas $\delta^{18} \mathrm{O}_{\mathrm{SO}_{4}}$ will vary $(+10 \%$ o to $-10 \%$ ), depending on the importance of high ${ }^{18} \mathrm{O}$ atmospheric oxygen or low- $-{ }^{18} \mathrm{O}$ water in the oxidation of pyrite. Recent studies (Rye et al., 2003) of Mount Rainier debris-flow deposits indicate that a significant amount of pre-collapse jarosite is present in the matrix, and that pyrite is present in about $30 \%$ of the small clasts. The formation of some of the Fe- and $\mathrm{Al}$ hydroxysulfates and gypsum has been attributed to the recent oxidation of this pyrite. Pyrite observed on present-day summit rocks is also being oxidized to hydroxysulfates. The rather abundant jarosite observed along fractures on summit scarps is probably also derived from the oxidation of pyrite.

\subsubsection{Recycled sulfate}

Aluminum- and Fe-hydroxysulfate minerals, gypsum, and anhydrite are highly soluble and subject to solution and re-deposition at the surface of active volcanoes as the minerals go through surficial wet and dry periods related to seasonal climate and to variations in the rates of degassing. Probably all soluble sulfates go through many cycles of dissolution and re-precipitation, as do the sulfate minerals in acid mine drainage (Bigham and Nordstrom, 2000). Soluble Al- and Fe-hydroxysulfates and gypsum are widespread in altered rock at Mount Adams, Mount Rainier, Mount Shasta, Citlaltépetl, and within the Osceola mudflow deposits. 


\subsection{Stable-isotope data}

Stable-isotope data are summarized in Table 2. The $\delta^{34} \mathrm{~S}$ and $\delta^{18} \mathrm{O}$ variations in the sulfate minerals are summarized in Fig. 18 , and the $\delta \mathrm{D}$ and $\delta^{18} \mathrm{O}_{\mathrm{SO}}$ values of alunite and the calculated compositions of water in their parent fluids for an assumed temperature range of $150-350{ }^{\circ} \mathrm{C}$ are summarized in Fig. 19. Detailed interpretations of stable-isotope data require detailed geological and petrological data which are currently not available for these volcanoes. Therefore, only general interpretations can be made. Signifi- cantly, in Fig. 18 and Table 2 the range of $\delta^{34} \mathrm{~S}$ values $(-2.6 \%$ to $3.5 \%$ ) for reduced-sulfur minerals (native sulfur and pyrite), is much less than the combined range (3\%o to $17 \%$ ) for the sulfate minerals alunite, jarosite, gypsum, and the soluble hydroxysulfates. These sulfur-isotope systematics, in which most of the isotopic variation is in the sulfate minerals, indicate that the parent volcanic fluids were sulfide dominant and that sulfur-isotope exchange of aqueous sulfate with a greater amount of relatively isotopically constant $\mathrm{H}_{2} \mathrm{~S}$ produced the range of $\delta^{34} \mathrm{~S}$ values in the sulfate minerals (Ohmoto, 1972; Rye, 1993; Rye,

Table 2

Stable isotope data of sulfate minerals, sulfur and pyrite from Cascade volcanoes and Citlaltépetl

\begin{tabular}{|c|c|c|c|c|c|c|c|c|c|c|c|}
\hline Volcano & Sample & Mineral $^{\mathrm{a}}$ & $\delta^{34} \mathrm{~S}$ & $\delta^{18} \mathrm{O}_{\mathrm{SO}_{4}}$ & $\delta \mathrm{D}$ & Volcano & Sample & Mineral $^{\mathrm{a}}$ & $\delta^{34} \mathrm{~S}$ & $\delta^{18} \mathrm{O}_{\mathrm{SO}_{4}}$ & $\delta \mathrm{D}$ \\
\hline \multirow[t]{17}{*}{ Adams } & MA 9903 & Alunite & & 3.0 & -129 & Rainier Edifice & $21 \mathrm{~B}$ & Alunite & 7.5 & 9.5 & -121 \\
\hline & MA 9905 & Alunite & 4.2 & 8.5 & -129 & & $169 \mathrm{~A}$ & Alunite & 17.3 & 15.0 & -85 \\
\hline & MA 9911 & Alunite & 5.4 & 11.4 & -123 & & $23 \mathrm{~A}$ & Jarosite & 3.1 & -9.0 & \\
\hline & MA 9918 & Alunite & 3.6 & 9.5 & -88 & & $23 \mathrm{~B}$ & Jarosite & 3.3 & -4.3 & -146 \\
\hline & MA $98 \mathrm{NS}$ & Alunite & 5.6 & 5.0 & -113 & & $24 \mathrm{~A}$ & Jarosite & 1.3 & & \\
\hline & MA 9901 & Gypsum & 4.0 & 3.9 & & & $24 \mathrm{D}$ & Jarosite & -1.2 & & \\
\hline & MA 9805 & Gypsum & 3.3 & 2.8 & & & $169 \mathrm{C}$ & Jarosite & 1.5 & -12.3 & -135 \\
\hline & MA 9826 & Gypsum & 4.1 & 2.3 & & & $170 \mathrm{~B}$ & Jarosite & 2.2 & -10.8 & -174 \\
\hline & MA 9806 & Gypsum & 4.6 & 7.2 & & & MRVB17 & Jarosite & 4.6 & & \\
\hline & MA 9901 & Gypsum & 4.0 & -3.3 & & & MRVB15 & Jarosite & 2.7 & & \\
\hline & MARW05 & Gypsum & 3.7 & 5.4 & & & 167 & Gypsum & 7.5 & & \\
\hline & MA 9916 & Soluble/Gypsum & 4.4 & -0.9 & & & 20 & Gypsum & 7.1 & 4.2 & \\
\hline & MA 9826 & Soluble & 3.3 & 2.0 & & & 196 & Gypsum & 3.6 & -4.0 & \\
\hline & MA 9905 & Soluble & -0.3 & -7.1 & & & 124 & Gypsum & 10.7 & 7.3 & \\
\hline & MA 9903 & Soluble & 2.9 & & & & FNK-1 & Gypsum & 6.9 & -1.6 & \\
\hline & MA 9918 & Soluble & 4.3 & & & & S.A. & Pyrite & 0.4 & & \\
\hline & Adams S & Sulfur & 3.0 & & & Citlaltépetl & PO-0003 & Alunite & 16.5 & 25.3 & -45 \\
\hline \multirow[t]{15}{*}{ Shasta } & MS 9803 & Alunite & 4.0 & 5.1 & -130 & & PO-0010b & Alunite & 11.0 & 13.5 & -41 \\
\hline & MS 9805 & Gypsum & 5.1 & 13.7 & & & PO-0017 & Alunite & 12.1 & 15.2 & -47 \\
\hline & MS 9903 & Gypsum & 6.9 & 27.8 & & & PO-0022 & Alunite & 17.1 & 27.5 & -50 \\
\hline & MS 9911 & Soluble/Gypsum & 3.0 & 28.1 & & & PdO 9902 & Alunogen & 8.1 & & \\
\hline & MS 9913 & Soluble/Gypsum & 4.1 & 29.9 & & & PdO 9904 & $\mathrm{Na}$ alum & 8.5 & & \\
\hline & MS 9915 & Soluble/Gypsum & 3.3 & 7.3 & & & PO-0010a & Soluble & 1.2 & 2.6 & \\
\hline & MS 9704B & Soluble & 4.4 & 29.8 & & & PO-0013 & Soluble/Gypsum & 10.6 & 21.0 & \\
\hline & MS 9712 & Soluble & 5.7 & 25.5 & & & PO-0016 & $\mathrm{K}$ alum & 7.2 & & \\
\hline & MS 9802 & Soluble & 5.6 & 5.3 & & & PO-0019 & $\mathrm{K}$ alum & 6.5 & 8.2 & \\
\hline & MS 9916 & Soluble & 2.8 & 2.9 & & & PO-0020 & Soluble & 8.2 & & \\
\hline & MS 9919 & Soluble & 1.0 & -2.1 & & & PO-0021 & $\mathrm{K}$ alum & 5.7 & 9.8 & \\
\hline & MS 9904 & Soluble & 5.6 & & & & Summit & Sulfur & -2.6 & & \\
\hline & MS 9901 & Soluble & 4.9 & & & & PdO99NS & Sulfur & -2.4 & & \\
\hline & MS 9801 & Pyrite & -0.3 & & & & PO-0011 & Sulfur & -1.8 & & \\
\hline & Shasta S & Sulfur & 3.5 & & & & PO-0012 & Sulfur & -2.2 & & \\
\hline \multirow[t]{4}{*}{ Hood } & MH 9907 & Alunite & & 10.2 & & & & & & & \\
\hline & MH alunite & Alunite & & 9.9 & & & & & & & \\
\hline & MH99NS & Soluble & 5.1 & & & & & & & & \\
\hline & MH 9903 & Sulfur & -1.0 & & & & & & & & \\
\hline
\end{tabular}

${ }^{\text {a }}$ Soluble/Gypsum=largely gypsum; Soluble= largely $\mathrm{K}$ or Na alum. 


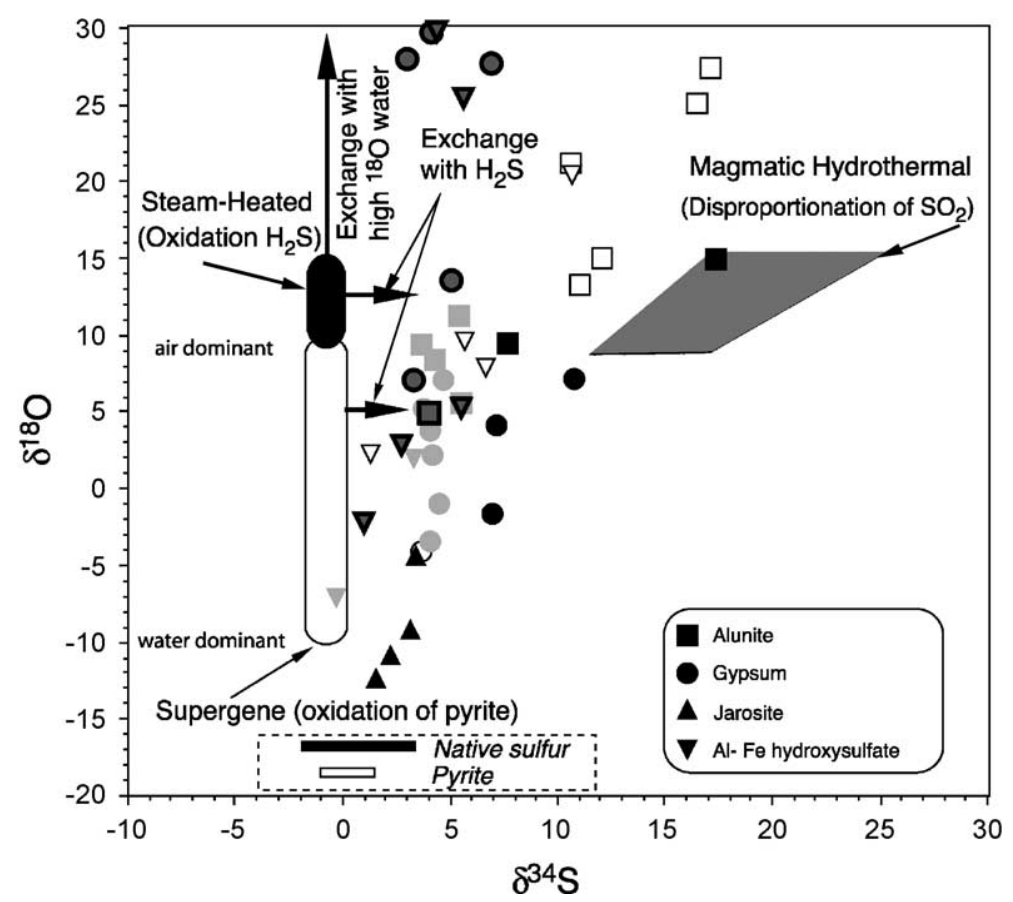

Fig. 18. Summary of the $\delta^{34} \mathrm{~S}$ and $\delta^{18} \mathrm{O}_{\mathrm{SO}_{4}}$ data on alunite, jarosite, gypsum, and soluble Al- and Fe-hydroxysulfates, Mount Adams (shaded), Mount Rainier (open), Mount Shasta (bold outlined), and Citlaltépetl (solid). $\delta^{34} \mathrm{~S}$ data on sulfur and pyrite in dashed box. Data fields are from Rye et al. (1992) for assumed compositions of parent fluids. Vertical arrow shows possible ${ }^{18} \mathrm{O}$ exchange of $\mathrm{SO}_{4}^{2-}$ with isotopically enriched water; horizontal arrows show possible ${ }^{34} \mathrm{~S}$ exchange of $\mathrm{SO}_{4}^{2-}$ with $\mathrm{H}_{2} \mathrm{~S}$ prior to precipitation of minerals.

this volume). All of the data are consistent with the possibility that the volcanic-sourced fluids were sulfide rich and that the average $\delta^{34} \mathrm{~S}$ for bulk sulfur for the volcanic gases was within $2 \pm 2 \%$. This conclusion is consistent with the observation that, at the great depths $(>6 \mathrm{~km})$ of the magmas for many active andesite stratovolcanoes, $\mathrm{H}_{2} \mathrm{~S}$ will likely be the dominant sulfur species in the evolved fluids (e.g., Gerlach and Casadevall, 1986; Symonds et al., 1994). However, notable exceptions in which the fluids are $\mathrm{SO}_{2}$-rich at great depth, such as the 1991 eruption of Mount Pinatubo (Philippines) have been observed (Rutherford and Devine, 1996). The differences in $\delta^{34} \mathrm{~S}$ values of bulk sulfur from volcano to volcano may reflect a history of prior magma degassing (Taylor, 1986).

With the exception of a group of samples from Mount Shasta, the data show a general positive correlation between $\delta^{34} \mathrm{~S}$ and $\delta^{18} \mathrm{O}$ values for sulfate minerals. This type of correlation has been observed in studies of many hydrothermal ore deposits (e.g., Bethke et al., this volume; Field et al., this volume).
At a fundamental level, the data reflect deposition over a range of temperatures and a mixing of aqueous sulfate, derived singularly or in combination either from magmatic-liquid fluids or the disproportionation of $\mathrm{SO}_{2}$, with the shallow sulfate derived from the oxidation of $\mathrm{H}_{2} \mathrm{~S}$ and (or) pyrite (Seal et al., 2000). Consistent with this interpretation are $\delta \mathrm{D}$ values of alunite that range from $-130 \%$ o to $-41 \%$ o (Fig. 19), and their calculated fluid compositions, which indicate both magmatic and meteoric water components. The large $\delta \mathrm{D}$ values easily identify magmatic water in large stratovolcanoes, even those situated at low latitudes like that of Citlaltépetl, because the $\delta \mathrm{D}$ value of precipitation can be expected to show a steep gradient related to elevation, such as the $65 \% \circ \mathrm{km}^{-1}$ noted for Mount Rainier (Frank, 1995). The range in $\delta \mathrm{D}_{\mathrm{H}_{2}} \mathrm{O}$ values of magmatic fluids may relate to Rayleigh isotopic fractionation effects in different batches of exsolved magmatic fluids (Taylor, 1986, 1991).

The $\delta^{34} \mathrm{~S}$ values of alunite from all volcanoes range from $4.2 \%$ to $17.3 \%$, and the $\delta^{18} \mathrm{O}_{\mathrm{SO}_{4}}$ values range from $3 \%$ to $27.5 \%$ o. The alunite samples with the 


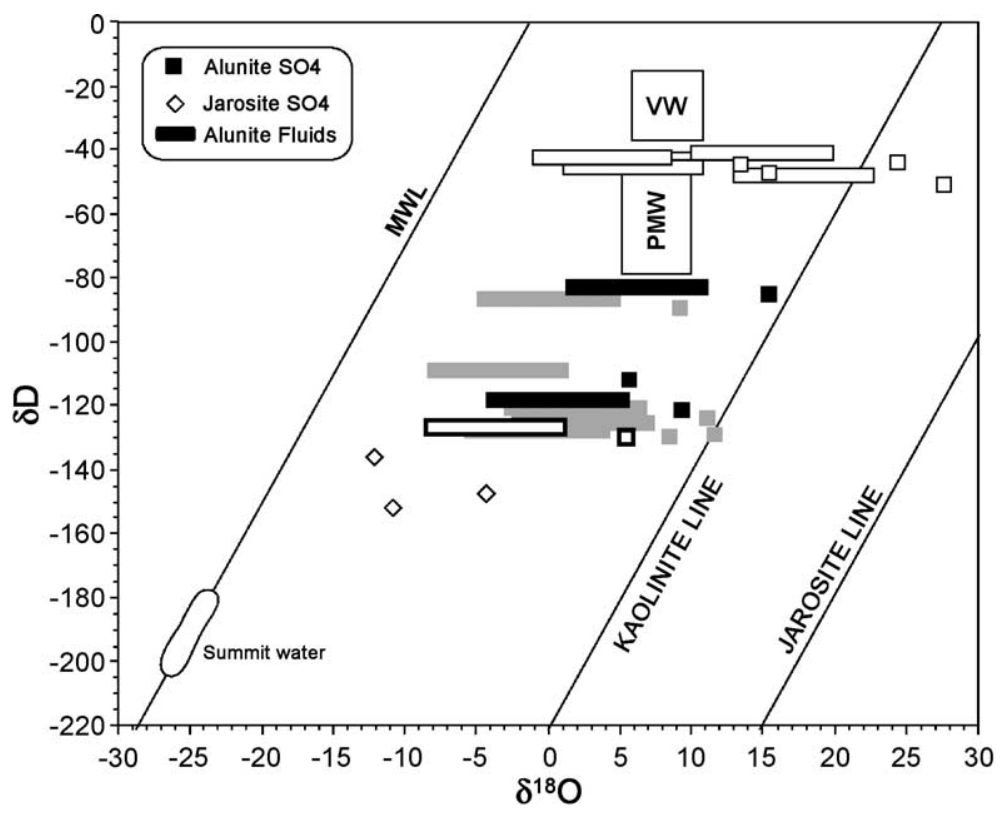

Fig. 19. Summary of alunite $\delta \mathrm{D}$ and $\delta^{18} \mathrm{O}_{\mathrm{SO}_{4}}$ data for Mount Adams (shaded), Mount Rainier (solid), Mount Shasta (bold outlined), and Citlaltépetl (open). Values for parent fluid for alunite are calculated for 150 to $350{ }^{\circ} \mathrm{C}$ using the equations of Stoffregen et al. (1994). Average value for summit meteoric water based on $\delta \mathrm{D} / \mathrm{km}$ decrease for precipitation on Mount Rainier (Frank, 1995). Parent fluids for supergene jarosite not shown because $\delta^{18} \mathrm{O}_{\mathrm{OH}}$ values needed to calculate $\delta^{18} \mathrm{O}_{\mathrm{H}_{2} \mathrm{O}}$ not analyzed. PMW, primary magmatic water reference of Taylor (1979); VW, arc-type magmatic water of Giggenbach (1992); the jarosite line of Rye and Alpers (1997); kaolinite line of Savin and Epstein (1970), and MWL, meteoric water line of Craig (1961).

largest $\delta^{34} \mathrm{~S}$ values from Mount Rainier and Citlaltépetl have the highest (least negative) $\delta \mathrm{D}$ values. These data imply that the parent aqueous sulfate for these alunite samples was derived from the disproportionation of $\mathrm{SO}_{2}$ in a magmatic-hydrothermal environment dominated by magmatic fluids (Rye et al., 1992). At Mount Rainier, this alunite is associated with pyrite $\left(\delta^{34} \mathrm{~S}=0.4 \%\right.$ ) . At Citlaltépetl, only native sulfur $\left(\delta^{34} \mathrm{~S}=-1.8 \%\right.$ to $-2.6 \%$ ) was collected. With a presumed $\delta^{34} \mathrm{~S}$ of $2 \%$ o to $-2 \%$ o for coexisting $\mathrm{H}_{2} \mathrm{~S}$, the $\delta^{34} \mathrm{~S}$ values of the alunite from Mount Rainier and Citlaltépetl give a calculated depositional temperature of about $350 \pm 50{ }^{\circ} \mathrm{C}$ based on empirical equations of Ohmoto and Lasaga (1982). The range of $\delta^{18} \mathrm{O}_{\mathrm{SO}_{4}}$ values also indicates that parent aqueous sulfate exchanged oxygen with both magmatic and meteoric fluids. Only the isotopically heavy alunites from Mount Rainier (collected at an erosion surface) and Citlaltépetl (summit scarps) have definite mineralogic characteristic and isotopic values consistent with a magmatic-hydrothermal origin. The low $\delta^{34} \mathrm{~S}$ values for some samples of alunite from Mount Shasta and
Mount Adams indicate that their aqueous sulfate did not equilibrate with $\mathrm{H}_{2} \mathrm{~S}$ and was derived from either (1) the oxidation of isotopically light $\mathrm{H}_{2} \mathrm{~S}$, with limited exchange of the resulting aqueous sulfate with fumarolic $\mathrm{H}_{2} \mathrm{~S}$ prior to deposition as alunite, or (2) the disproportionation of $\mathrm{SO}_{2}$, with only limited sulfur isotopic exchange between aqueous sulfate and $\mathrm{H}_{2} \mathrm{~S}$. The latter could occur as magmatic gases are scrubbed (Symonds et al., 2001) by low-temperature groundwaters near the surface. The $\delta^{34} \mathrm{~S}$ and $\delta^{18} \mathrm{O}$ data for Mount Shasta follow a near-vertical trend at low $\delta^{34} \mathrm{~S}$ values, and some $\delta^{18} \mathrm{O}_{\mathrm{SO}_{4}}$ values are exceptionally high. The narrow range of low $\delta^{34} \mathrm{~S}$ values may indicate that the sulfate was derived largely from oxidation of $\mathrm{H}_{2} \mathrm{~S}$ in a steam-heated environment. The large $\delta^{18} \mathrm{O}_{\mathrm{SO}_{4}}$ values probably reflect oxygen isotope exchange between aqueous sulfate and ${ }^{18} \mathrm{O}$-enriched water prior to precipitation of sulfate minerals. Sulfate-water oxygen isotope fractionations are only about $30 \%$ at $25{ }^{\circ} \mathrm{C}$ (Stoffregen et al., 1994). Thus, the exchange water must have been ${ }^{18} \mathrm{O}$-enriched magmatic or highly evapo- 
rated or exchange meteoric fluids, such as observed in a crater lake at Poas Volcano, Costa Rica (Rowe, 1994). In support of a steam-heated rather than a supergene origin for sulfate at Mount Shasta, airborne visible/infrared imaging spectrometry (AVIRIS) combined with field-based mineralogical studies did not detect jarosite on the volcano (J. Crowley, personal communication, 2001).

Gypsum is common around fumaroles in stratovolcanoes (e.g., Lovering, 1957; Stoiber and Rose, 1974; Monaco and Valette, 1978; Kodosky and Keskinen, 1990; Kavalieris, 1994; Getahun et al., 1996; Symonds et al., 1996; Goff and McMurtry, 2000). The overall distribution for the gypsum $\delta^{34} \mathrm{~S}$ and $\delta^{18} \mathrm{O}$ data (Fig. 18) is the same as for soluble Feand Al-hydroxysulfates. These minerals frequently occur together, and the similarity in their isotope data indicates a similar origin for their aqueous sulfate. Micro-crystals of barite are observed around fumaroles at Citlaltépetl. Transport of $\mathrm{Ba}$ in a volcanic vapor fluid has been documented for the magmaticsteam alunite at Alunite Ridge near Marysvale, Utah (Cunningham et al., 1996) and in Ba-rich analogues of magmatic-steam alunite at the El Indio district, Chile (Deyell et al., this volume). The coarse anhydrite/ gypsum-containing barite crystals with saline fluid inclusions having a temperature of $235 \pm 25{ }^{\circ} \mathrm{C}$ have high $\delta^{34} \mathrm{~S}$ values. The $\delta^{34} \mathrm{~S}$ and $\delta^{18} \mathrm{O}$ values (Fig. 18) are consistent with an origin from magmatic sulfate that mixed with meteoric water containing sulfate derived from the oxidation of $\mathrm{H}_{2} \mathrm{~S}$ or pyrite. Barite and anhydrite precipitation can occur during the mixing of sulfate-rich saline and dilute fluids (Holland and Malinin, 1979).

The jarosite samples from Mount Rainier have low $\delta^{34} \mathrm{~S}$ and $\delta^{18} \mathrm{O}$ values; the latter are the lowest recorded for the mineral (Rye and Alpers, 1997), indicating that jarosite formed from aqueous sulfate derived from the oxidation of pyrite in meteoric water. The authors' (Rye et al., 2003) recent studies of the Osceola mudflow deposit indicate that a high percentage of coarse fragments contain a pyritic assemblage undergoing oxidation to soluble sulfates and gypsum. Although the relative importance of the oxidation of $\mathrm{H}_{2} \mathrm{~S}$ versus pyrite in the formation of jarosite needs further study, much of the jarosite on Mount Rainier may have been derived from the oxidation of pyrite.

\subsection{Relationships between sulfate-bearing hydro- thermally altered rock and edifice collapse}

Edifice collapse represents the most important volcanic hazard in the Cascade Range (National Research Council, 1994; Crandell et al., 1984) and at Citlaltépetl (Carrasco-Núñez and Gomez-Tuena, 1997). At these volcanoes, all of the largest collapse events have included extensive volumes of altered rock that contain sulfate minerals (e.g., Crandell, 1971; Carrasco-Núñez et al., 1993). Very large volume failures $\left(n \times 10^{9} \mathrm{~m}^{3}\right)$, such as those from Citlaltépetl, Mount Rainier, and Mount Shasta, represent catastrophic, although infrequent, hazards. Failures of more moderate size $\left(n \times 10^{6} \mathrm{~m}^{3}\right)$ occur relatively frequently, but travel shorter distances, representing important hazards to proximal surroundings, including campgrounds, highways, and buildings.

Hydrothermal alteration has been shown to structurally weaken volcanic rocks, with edifice collapse leading to debris avalanches (Bowman et al., 1999; Watters et al., 2000). To determine the possible specific role of acid-sulfate alteration in edifice collapse would require a detailed study of each volcano, which is beyond the scope of this study. As an example of the type of information that may be derived from such studies, the matrix of debrisavalanche deposits from a major edifice collapse on Mount Rainier contains the assemblage jarosite+ smectite, and about $30 \%$ of the small clasts contain pyrite+smectite (Rye et al., 2003). The mineralogical, textural, and isotopic data indicate that the jarosite formed from the oxidation of pyrite above the water table on the pre-collapse summit. These observations suggest that the edifice, as it slid down the volcano, it broke along fractures containing supergene jarosite. The dominant alteration assemblages exposed after major edifice collapse on Mount Rainier and other volcanoes, such as Citlaltépetl and, are alunite+kaolinite + silica \pm pyrite, which form below the water table. Thus, perhaps, the location of the water table during supergene alteration of hydrothermal pyrite, as well as the distribution of hydrothermal and supergene alteration along major structures, may have been important in edifice collapse.

Secondary sulfate minerals commonly found on stratovolcanoes are due to both hydrothermal and supergene processes. Most of these processes lead to 
acid-sulfate alteration which may weaken the volcanic edifice. The hydrothermal minerals are related to different processes that occur throughout the edifice but are likely to be restricted to major structures that provide conduits for magmatic gases. Many stratovolcanoes have glaciers whose melt waters serve as an effective trap for acid gases. Hydrothermal alteration thus represents a relatively constant feature of the instability of the volcanoes. The supergene phases develop from the oxidation of hydrothermal pyrite but their distribution will be tied to cycles of weathering and mass wasting which in turn are heavily dependant on climate and intermittent volcano activity.

\section{Conclusions}

Sulfate-bearing hydrothermal alteration in active stratovolcanoes occurs episodically when sulfur-rich volcanic gases are introduced into meteoric water, with subsequent formation of acids that are neutralized by reaction with volcanic rock. Because of the complex nature of hydrothermal systems in active stratovolcanoes, disequilibrium sulfate-mineral assemblages are common although most mineral assemblages can be explained by variations in the cation chemistry and $\mathrm{pH}$ of their parent solutions. The general sequence with decreasing $\mathrm{pH}$ is simple sulfates, alunite, jarosite, and soluble hydroxysulfates. Stable-isotope data help define the processes that produce aqueous sulfate in different stratovolcano environments. The $\delta \mathrm{D}$ and $\delta^{18} \mathrm{O}_{\mathrm{SO}_{4}}$ data for alunite reflect the role of magmatic fluids in the origin of the mineral; similarly, the $\delta^{18} \mathrm{O}_{\mathrm{SO}_{4}}$ data for jarosite reflect the role of meteoric water. The $\delta^{34} \mathrm{~S}$ and $\delta^{18} \mathrm{O}_{\mathrm{SO}_{4}}$ data reflect the importance of both the disproportionation of $\mathrm{SO}_{2}$ and the oxidation of pyrite $\left(\right.$ or $\mathrm{H}_{2} \mathrm{~S}$ ) in the formation of aqueous sulfate. The $\delta^{34} \mathrm{~S}$ data are consistent with the high $\mathrm{H}_{2} \mathrm{~S}_{/} \mathrm{SO}_{2}$ expected for volcanic gases from deep andesitic magmas whose bulk $\delta^{34} \mathrm{~S}_{\sum \mathrm{S}}$ is within $2 \pm 2 \%$ o.

Alunite-group minerals form in association with kaolinite and silica in deep magmatic hydrothermal to surface-fumarole environments. Most alunite on stratovolcanoes probably forms from aqueous sulfate derived from the disproportionation of $\mathrm{SO}_{2}$. Classical magmatic-hydrothermal alunite associated with pyrite and having $\delta^{34} \mathrm{~S}$ values that reflect equilibrium between aqueous sulfur species in parent fluids at high temperatures is observed where the interior of a volcano has been exposed by edifice collapse or erosion. Anhydrite veins with barite, which form from mixing of saline magmatic fluids with dilute meteoric waters, may also occur in the shallow interior of the edifice. Alunite-group minerals with $\delta^{34} \mathrm{~S}$ values indicating disequilibrium among sulfur species in parental fluids may form from aqueous sulfate derived from disproportionation of $\mathrm{SO}_{2}$ scrubbed by lowtemperature groundwater or from the oxidation of $\mathrm{H}_{2} \mathrm{~S}$. Alunite may also form as a fumarole sublimate. Jarosite-group minerals, usually in association with smectite and silica, form above the water table from sulfuric acid produced by the supergene oxidation of pyrite. An unknown amount of jarosite probably also forms from the oxidation of $\mathrm{H}_{2} \mathrm{~S}$ in volcanic gases. Soluble Fe- and Al-hydroxysulfates form from the oxidation of pyrite on summits and debris flows. The hydroxysulfates, along with gypsum, also form as sublimates from fumaroles or from the evaporation of acid fluids. Occasionally, barite forms around fumaroles. Soluble hydroxysulfates and gypsum probably go through many cycles of solution and precipitation.

Acid-sulfate alteration may lead to structural weakening and collapse of a volcanic edifice. Our results suggest that jarosite-group minerals that form above the water table and occur with swelling clays (smectite) may be important indicators of edifice instability in some volcanoes. Massive zones of alunite-group minerals associated with kaolinite \pm pyrite and veins of gypsum, which form below the water table, are more dominant in the remnant cores of volcanic edifices where major collapses or erosion have exhumed deeper parts of ancestral edifices. Future studies are needed to determine the degree to which hydrothermal alteration, supergene alteration of pyrite, or the location of paleo-water tables affect volcano edifice collapse.

\section{Acknowledgements}

This work was partly supported by NASA grants NAG5-7579 and NAG5-9497 and by the US Geological Survey's Mineral Resource Program. We are grateful to Vicky Bruce, Annemarie van Bieman, Cyndi Kester, Pam Gemery, and Carol Gent for help 
with the mineral separations and stable-isotope analyses. This paper was reviewed at various stages and greatly improved by Jim Luhr, Bob Seal, Phil Bethke and Geoff Plumlee. [PD]

\section{References}

Africano, F., Bernard, A., 2000. Acid alteration in the fumarolic environment of Usu Volcano, Hokkaido. Japan. J. Volcanol. Geotherm. Res. 97, 475-495.

Andres, R.J., Kasgnoc, A.D., 1998. A time-averaged inventory of subaerial volcanic sulfur emissions. J. Geophys. Res. 103, 25251-25261.

Arribas Jr., A., 1995. Characteristics of high-sulfidation epithermal deposits and their relation to magmatic fluid. In: Thompson, J.F.H. (Ed.), Magmas, Fluids, and Ore Deposits, Mineral. Assoc. Canada Short Course, vol. 23, pp. 419-454.

Bargar, K.E., Keith, T.E.C., Beeson, M.H., 1993. Hydrothermal alteration in the Mount Hood area, Oregon. U.S. Geol. Surv. Monogr., B 2054, 70.

Bethke, C.M., 1998. The Geochemist's Workbench Release 3.0. University of Illinois, Urbana.

Bethke, P.M., Rye, R.O., Stoffregen, R.E., Vikre, P., 2005. Evolution of the Summitville magmatic-hydrothermal acid-sulfate system: integration of geological, stable-isotope, and fluid-inclusion evidence. Chem. Geol. 215, 281-315 (this volume).

Bigham, J.M., Nordstrom, D.K., 2000. Iron and aluminum hydroxysulfates from acid sulfate waters. In: Alpers, C.N., Jambor, J.L., Nordstrom, D.K. (Eds.), Sulfate MineralsCrystallography, Geochemistry, and Environmental Significance, Rev. Mineral. Geochem., vol. 40, pp. 351-403.

Bowman, S.D., Watters, R.J., Zimbelman, D.R., Firth, I., 1999. Insights into edifice instability at Mount Adams, Washington. EOS, Trans., AGU 80 (46), 1151.

Brantley, S.R., Scott, W.E., 1993. The danger of collapsing lava domes: lessons for Mount Hood, Oregon. U.S. Geol. Surv. Earthq. Volcanol. 24, 244-269.

Bruce, V.L., 1997. Geochemistry of hydrothermal alteration along a radial transect from the summit of Mount Rainier, Washington. MS. thesis, Univ. California, Riverside.

Cameron, K.A., Pringle, P.T., 1987. A detailed chronology of the most recent major eruptive period at Mount Hood, Oregon. Geol. Soc. Am. Bull. 99, 845-851.

Carrasco-Núñez, G., 1997. Lava flow growth inferred from morphometric parameters; a case study of Citlaltépetl volcano, Mexico. Geology 134, 151-162.

Carrasco-Núñez, G., Gomez-Tuena, A., 1997. Volcanogenic sedimentation around Citlaltépetl (Pico de Orizaba) volcano and surroundings, Veracruz, Mexico. IAVCEI General Assembly excursions: Mexico. D.F., UNAM, Inst. Geol. Excursion 16, $131-151$.

Carrasco-Núñez, G., Vallance, J.W., Rose, W.I., 1993. A voluminous avalanche-induced lahar from Citlaltépetl Volcano, Mexico. Implications for hazard assessment. J. Volcanol. Geotherm. Res. 59, 35-46.
Clarke, S.H., Carver, G.A., 1992. Late Holocene tectonics and paleoseismicity, southern Cascadia subduction zone. Science $255,188-192$.

Craig, H., 1961. Isotopic variation of meteoric water. Science 133, $1702-1703$.

Crandell, D.R., 1971. Postglacial lahars from Mount Rainier Volcano, Washington. U.S. Geol. Surv. Prof. Pap., 677.

Crandell, D.R., 1976. The geologic story of Mount Rainier. U.S. Geol. Surv., 1292.

Crandell, D.R., 1980. Recent eruptive history of Mount Hood, Oregon, and potential hazards from future eruptions. U.S. Geol. Surv., 1492.

Crandell, D.R., 1989. Gigantic debris avalanche of Pleistocene age from ancestral Mount Shasta volcano, California, and debrisavalanche hazard zonation. U.S. Geol. Surv. Bull., 1861.

Crandell, D.R., Miller, C.D., Glicken, H.X., Christiansen, R.L., Newhall, C.G., 1984. Catastrophic debris avalanche from ancestral Mount Shasta volcano, California. Geology 12, $143-146$.

Crowley, J.K., Zimbelman, D.R., 1997. Mapping hydrothermally altered rocks on Mount Rainier, Washington, with Airborne Visible/Infrared Imaging Spectrometer (AVIRIS) data. Geology $25,559-562$.

Cunningham, C.G., Rye, R.O., Bethke, P.M., Logan, M.A.V., 1996. Formation of coarse-grained vein alunite during degassing of an epizonal stock. Chapman Conference on Crater Lakes, Terrestrial Degassing and Hyper-Acid Fluids in the Environment, Sept. 4-9. Crater Lake, OR. Am. Geophys. Union, Washington, DC, p. 27 (abs.).

Deyell, C, Rye, R.O., Landis, G.P., Bissig, T., 2005. Alunite and the role of magmatic fluids in the Tambo high-sulfidation deposit, El Indio-Pascua belt, Chile. Chem. Geol. 215, 185218 (this volume).

Ebert, S.W., Rye, R.O., 1997. Secondary precious metal enrichment by steam-heated fluids in the Crofoot-Lewis hot spring goldsilver deposit and relation to paleoclimate. Econ. Geol. 92, $578-600$.

Field, C.W., Zhang, L., Dilles, J.H., Rye, R.O., Reed, M.H., 2005. Sulfur and isotopic record in sulfate and sulfide minerals of early, deep, pre-Main stage porphyry $\mathrm{Cu}-\mathrm{Mo}$ and late, shallow Main Stage base-metal mineral deposits, Butte district, Montana. Chem. Geol. 215, 61-93 (this volume).

Fiske, R.S., Hopson, C.A., Waters, A.C., 1963. Geology of Mount Rainier National Park, Washington. U.S. Geol. Surv. Prof. Pap., 444.

Fournier, R.O., 1987. Conceptual model of brine evolution. U.S. Geol. Surv. Prof. Pap. 1350 (2), 1487-1506.

Fowler, C.S., 1934. The sulphur deposits of Mount Adams, Yakima county, Washington. Unpub. report for Glacier Mining Company, White Salmon, Washington.

Frank, D., 1995. Surficial extent and conceptional model of hydrothermal system at Mount Rainier, Washington. J. Volcanol. Geotherm. Res. 65, 51-80.

Gerlach, T.M., Casadevall, T.J., 1986. Fumarole emissions at Mount St. Helens volcano, June 1980 to October 1981: degassing of a magma-hydrothermal system. J. Volcanol. Geotherm. Res. 28, $141-160$. 
Getahun, A., Reed, M., Symonds, R., 1996. Mount St. Augustine Volcano fumarole wall rock alteration: mineralogy, zoning, composition and numerical models of its formation process. J. Volcanol. Geotherm. Res. 71, 73-107.

Giggenbach, W.F., 1992. Isotopic shifts in waters from geothermal and volcanic systems along convergent plate boundaries and their origin. Earth Planet. Sci. Lett. 113, 495-510.

Giggenbach, W.F., 1997. The origin and evolution of fluids in magmatic-hydrothermal systems. In: Barnes, H.L. (Ed.), Geochemistry of Hydrothermal Ore deposits, 3rd ed. John Wiley and Sons, New York, pp. 737-796.

Goff, F., McMurtry, G.M., 2000. Tritium and stable isotopes of magmatic waters: Crater Lakes Monograph. J. Volcanol. Geotherm. Res. 97, 347-396.

Henley, R.W., Ellis, A.J., 1983. Geothermal systems ancient and modern: a geochemical review. Earth Sci. Rev. 19, 1-50.

Henley, R.W., McNabb, A., 1978. Magmatic vapor plumes and ground-water interaction in porphyry copper emplacement. Econ. Geol. 73, 1-20.

Hildreth, W., Fierstein, J., 1995. Geologic map of the Mount Adams volcanic field, Cascade Range of southern Washington. U.S. Geol. Surv. Misc. Invest. Map I-2460.

Hildreth, W., Lanphere, M.A., 1994. Potassium-argon geochronology of a basalt-andesite-dacite arc system: the Mount Adams volcanic field, Cascade Range of southern Washington. Geol. Soc. Am. Bull. 106, 1413-1429.

Holland, H.D., 1965. Some applications of thermochemical data in problems of ore deposits II: mineral assemblages and the composition of ore-forming fluids. Econ. Geol. 60, 1101-1166.

Holland, H.D., Malinin, S.D., 1979. The solubility and occurrence of non-ore minerals. In: Barnes, H.L. (Ed.), Geochemistry of Hydrothermal Ore Deposits, 2nd ed. John Wiley and Sons, New York, pp. 461-508.

Hoskuldsson, A., Cantagrel, J.M., 1994. Volcanic hazards in the surroundings of Pico de Orizaba, Eastern Mexico. Nat. Hazards 10, 197-219.

Hoskuldsson, A., Robin, C., 1993. Late Pleistocene to Holocene eruptive activity of Pico de Orizaba, Eastern Mexico. Bull. Volcanol. 55, 571-587.

Kavalieris, I., 1994. High Au, Ag, Pb, V and W content of fumarolic deposits at Merapi Volcano central Java, Indonesia. J. Geochem. Explor. 50, 479-491.

Kodosky, L.G., Keskinen, M., 1990. Fumarole distribution, morphology, and encrustation mineralogy associated with the 1986 eruptive deposits of Mount St. Augustine, Alaska. Bull. Volcanol. 52, 175-185.

Lopez, D.L., Williams, S.N., 1993. Catastrophic volcanic collapse: relation to hydrothermal processes. Science 260, 1794-1796.

Lovering, T.S., 1957. Halogen-acid alteration of ash at Fumarole No. 1, Valley of Ten Thousand Smokes, Alaska. Geol. Soc. Am. Bull. 68, 1585-1603.

Miller, C.D., 1980. Potential hazards from future eruptions in the vicinity of Mount Shasta volcano, northern California. U.S. Geol. Surv. Bull. 1503, 43.

Monaco, A., Valette, J.N., 1978. Etude des produits d'alteration fumerollienne et meteorique a Vulcano (Iles Eoliennes, Italie).
Fumarolic and meteoritic alteration products at Vulcano, Lipari Islands, Italy. Clay Miner. 13, 79-91.

Moran, S.C., Zimbelman, D.R., Malone, S.D., 2000. A model for the magmatic-hydrothermal system at Mount Rainier, Washington, from seismic and geochemical observations. Bull. Volcanol. 61, 425-436.

National Research Council, 1994. Mount Rainier, Active Cascade Volcano. National Academies Press, Washington, DC.

Ohmoto, H., 1972. Systematics of sulfur and carbon isotopes in hydrothermal ore deposits. Econ. Geol. 67, 497-510.

Ohmoto, H., Goldhaber, M.B., 1997. Sulfur and carbon isotopes. In: Barnes, H.L. (Ed.), Geochemistry of Hydrothermal Ore deposits, 3rd ed. John Wiley and Sons, New York, pp. 517-612.

Ohmoto, H., Lasaga, A.C., 1982. Kinetics of reactions between aqueous sulfates and sulfides in hydrothermal systems. Geochim. Cosmochim. Acta 46, 1727-1745.

Rowe Jr., G.L., 1994. Oxygen, hydrogen, and sulfur isotope systematics of the crater lake system of Poás Volcano, Costa Rica. J. Volcanol. Geotherm. Res. 28, 263-287.

Rutherford, M.J., Devine, J.D., 1996. Preeruption pressuretemperature conditions and volatiles in the 1991 dacitic magma of Mount Pinatubo. In: Newhall, C.G., Punongbayan, R.S. (Eds.), Fire and Mud-eruptions and Lahars of Mount Pinatubo, Philippines, PHIVOLCS and Univ. Washington Press, pp. 751-766.

Rye, R.O., 1993. The evolution of magmatic fluids in the epithermal environment. The stable isotope perspective. Econ. Geol. 88, $733-753$.

Rye, R.O., 2005. A review of the stable-isotope geochemistry of sulfate minerals in volcanic environments and related hydrothermal systems. Chem. Geol. 215, 5-36 (this volume).

Rye, R.O. Alpers, C.N., 1997. The stable isotope geochemistry of jarosite. U.S. Geol. Surv. Open-File Rep. 97-88.

Rye, R.O., Bethke, P.M., Wasserman, M.D., 1992. The stable isotope geochemistry of acid sulfate alteration. Econ. Geol. 87, 225-262.

Rye, R.O., Bethke, P.M., Lanphere, M.A., Steven, T.A., 2000. Neogene geomorphic and climatic evolution of the central San Juan Mountains, Colorado: K/Ar age and stable isotope data on supergene alunite and jarosite from the Creede mining district. In: Bethke, P.M., Hay, R.L. (Eds.), Ancient Lake Creede: Its Volcano-Tectonic Setting, History of Sedimentation, and Relation to Mineralization in the Creede Mining District, Geol. Soc. Am., Spec. Pap., vol. 346, pp. 95-103.

Rye, R.O., Breit, G.N., Zimbelman, D.R., 2003. Preliminary mineralogic and stable isotope studies of altered summit and flank rocks and Osceola mudflow deposits on Mount Rainier, Washington. U.S. Geol. Surv. Open-File Rept. 03-464.

Savin, S.M., Epstein, S., 1970. The oxygen and hydrogen isotope geochemistry of clay minerals. Geochim. Cosmochim. Acta 34, $24-42$.

Scott, W.E., Iverson, R.M., Vallance, J.W., Hildreth, W., 1995. Volcano hazards in the Mount Adams region, Washington. U.S. Geol. Surv. Open-File Rep. 95-492.

Scott, W.E., Pierson, T.C., Schilling, S.P., Costa, J.E., Gardner, C.A., Vallance, J.W., Major, J.J., 1997. Volcano hazards in the Mount Hood region, Oregon. U.S. Geol. Surv. Open-File Rep. 97-89. 
Seal II, R.R., Alpers, C.N., Rye, R.O., 2000. Stable isotope systematics of sulfate minerals. In: Alpers, C.N., Jambor, J.L., Nordstrom, D.K. (Eds.), Sulfate Minerals - Crystallography, Geochemistry, and Environmental Significance, Rev. Mineral. Geochem., vol. 40, pp. 541-602.

Sherrod, D.R., Smith, J.G., 1990. Quaternary extrusion rates of the Cascade Range, northwestern United States and southern British Columbia. J. Geophys. Res. 95, 19465-19474.

Sisson, T.W., Lanphere, M.A., 1999. The geologic history of Mount Rainier volcano, Washington. Northwest Scientific Assoc., 1999 Ann. Meet., Tacoma, WA, vol. 50 Abs.

Stanley, W.D., Johnson, S.Y., Qamar, A., Weaver, C.S., Williams, J.M., 1996. Tectonics and seismicity of the Southern Washington Cascade Range. Bull. Seismol. Soc. Am. 86, 1-18.

Stoffregen, R.E., 1993. Stability relations of jarosite and natrojarosite at $100-250{ }^{\circ} \mathrm{C}$. Geochim. Cosmochim. Acta 57, $2417-2429$

Stoffregen, R.E., Rye, R.O., Wasserman, M.D., 1994. Experimental studies of alunite: $\mathrm{I}^{18} \mathrm{O}^{16} \mathrm{O}$ and $\mathrm{D}-\mathrm{H}$ fractionation factors between alunite and water at $250-450{ }^{\circ} \mathrm{C}$. Geochim. Cosmochim. Acta 58, 903-916.

Stoiber, R.E., Rose Jr., W.I., 1974. Fumarole incrustations at active Central American volcanoes. Geochim. Cosmochim. Acta 38, $495-516$.

Symonds, R.B., Rose, W.I., Bluth, G.J.S., Gerlach, T.M., 1994. Volcanic-gas studies: methods, results, and applications. In: Carroll, M.R., Holloway, J.R. (Eds.), Volatiles in magmas, Rev. Mineral., vol. 30, pp. 1-66.

Symonds, R.B., Mitzutani, Y., Briggs, P.H., 1996. Long-term geochemical surveillance of fumaroles at Showa-Shinzan Dome, Usu Volcano, Japan. J. Volcanol. Geotherm. Res. 72, $177-211$.

Symonds, R.B., Gerlach, T.M., Reed, M.H., 2001. Magmatic gas scrubbing: implications for volcanic monitoring. J. Volcanol. Geotherm. Res., Giggenbach Meml. 108, 303-341.

Taylor Jr., H.P., 1979. Oxygen and hydrogen isotope relationships in hydrothermal mineral deposits. In: Barnes, H.E. (Ed.), Geo- chemistry of Hydrothermal Ore Deposits, 2nd ed. John Wiley and Sons, New York, pp. 236-277.

Taylor, B.E., 1986. Magmatic volatiles: isotopic variation of C, H, and S. In: Valley, J.W., Taylor Jr., H.P., O’Neil, J.R. (Eds.), Stable Isotopes in High Temperature Geological Processes, Rev. Mineral., vol. 16, pp. 185-225.

Taylor, B.E., 1991. Degassing of Obsidian Dome rhyolite, Inyo volcanic chain, California. In: Taylor Jr., H.P., O’Neil, J.R., Kaplan, I.R. (Eds.), Stable Isotope Geochemistry: A tribute to Samuel Epstein, Geochem. Soc. Spec. Pub., vol. 3, pp. 339-353.

Taylor, B.E., Wheeler, M.C., Nordstrom, D.K., 1984. Stable isotope geochemistry of acid mine drainage: experimental oxidation of pyrite. Geochim. Cosmochim. Acta 48, 2669-2678.

Vallance, J.W., 1999. Postglacial lahars and potential hazards in the White Salmon River system on the southwest flank of Mount Adams, Washington. U.S. Geol. Surv. Bull., 2161.

Wasserman, M.D., Rye, R.O., Bethke, P.M., Arribas, A., 1992. Methods for separation and total stable isotope analysis of alunite: U.S. Geol. Surv. Open-File Rep. 92-9.

Watters, R.J., Zimbelman, D.R., Bowman, S.D., Crowley, J.K., 2000. Rock mass strength assessment and significance to edifice stability, Mount Rainier and Mount Hood, Cascade Range volcanoes. Pure Appl. Geophys. 157, 957-976.

Watters, R.J., Bowman, S.D., Zimbelman, D.R., Firth, I.R., 2001. Geotechnical modeling studies of volcano collapse. Proc. 36th Ann. Symp. Eng. Geol. Geotech. Engineering, Las Vegas, Nevada, pp. 287-296.

Wise, W.S., 1968. Geology of the Mount Hood volcano. In: Hollis, M.D. (Ed.), Andesite Conference Guidebook, Or. Dep. Geol. Miner. Ind. Bull., vol. 62, pp. 81-98.

Zimbelman, D.R., 1996. Hydrothermal alteration and its influence on volcanic hazards-Mount Rainier, Washington, a case history. PhD thesis, Univ. Colorado, Boulder.

Zimbelman, D.R., Rye, R.O., Landis, G.P., 2000. Fumaroles in ice caves on the summit of Mount Rainier-preliminary stable isotope, gas, and geochemical studies. J. Volcanol. Geotherm. Res. 97, 457-473. 